\title{
The impact of EU and Non-EU immigration on British wages
}

\author{
Stephen Nickell ${ }^{1}$ and Jumana Saleheen ${ }^{2^{*}}$ (D)
}

\author{
* Correspondence: \\ Jumana.saleheen@bankofengland.co.uk \\ ${ }^{2}$ Bank of England, Threadneedle \\ Street, EC2R 8AH London, UK \\ Full list of author information is \\ available at the end of the article
}

\begin{abstract}
There is a consensus among academics that immigration has little or no effect on native British wages, but these studies have not refined their analysis by occupations. Our contribution is to extend the literature to incorporate occupations. Doing so, we find that immigration has a small negative impact on average British wages, with a somewhat larger impact within the semi/unskilled service occupations. This paper also explores if there is any differential impact between EU and non-EU immigration on wages. We find there to be none. These findings are likely to be useful for shaping future immigration policy in Britain.
\end{abstract}

JEL Classification: $J 6$

Keywords: Immigration, Occupation, Wages

\section{Introduction}

Immigration, and the impact that it may have on economy has wide ranging implication for both social and economic policy. It is for this reason that immigration in Europe, the US and elsewhere has often been a hotly debated and politically charged topic. Following EU expansion in 2004, the United Kingdom granted nationals from the new EU member states immediate free access to the UK labour market. Around that same time, the focus of the debate started to shift towards the immigrants that were coming from Europe. This among a variety of other concerns culminated in the 2016 British Referendum on EU membership.

It is probably fair to say that the rising worries surrounding immigration have partly reflected the sharp rise in immigration in recent decades. The number of immigrants entering and remaining in Britain has doubled in the past 25 years. For example, according to official figures, the net flow of immigration to the UK has risen in recent decades, reaching a record high of 335,000 in the year ending June 2016. This increased flow has also led to a rise in the stock of immigrants. The share of immigrants in the workforce has more than doubled, rising from below 10\% in 1992 to over 20\% in 2016. The nature of immigration has also changed, with the share of immigrants born in the EU rising threefold: from around $3 \%$ in the early 1990 s to nearly $10 \%$ in 2016.

At the heart of this debate is the widespread belief by the general public and policymakers that immigration has large effects on the labour market in general and employment and wages in particular. The stereotype of the Polish plumber used widely as a symbol of cheap labour - encapsulates the commonly held belief

(c) The Author(s). 2017 Open Access This article is distributed under the terms of the Creative Commons Attribution 4.0 International License (http://creativecommons.org/licenses/by/4.0/), which permits unrestricted use, distribution, and reproduction in any medium, provided you give appropriate credit to the original author(s) and the source, provide a link to the Creative Commons license, and indicate if changes were made. 
that immigration in Britain has pushed down wages in the jobs that have tended to be most affected by immigration.

This paper, based on Nickell and Saleheen (2015), asks whether these concerns are justified. It asks whether immigration to Britain has had any impact on average wages. And whether immigration from the EU is any different to immigration from elsewhere? Theory is an imperfect guide to answering these questions, so ultimately these are empirical questions that are addressed in this paper. ${ }^{1}$

We find that immigration has a small negative impact on average British wages. Our results also reveal that the biggest impact of immigration on wages is within the semi/ unskilled services occupational group, which have seen a large inflow of migration from the EU. We find no differential impact between EU and non-EU immigration on wages. These results are based on our empirical strategy of estimating a simple reduced form equation that relates the average wages (in a particular region and occupation) to the share of immigrants (in that same region and occupation). The equation also includes the unemployment rate, controls for age and education as well as region, time and occupation fixed effects. This reduced for equation drops out of a simple model of the demand and supply for labour, where labour supply is affected by immigration. We use data on immigration from the British Labour Force Survey (LFS) and data on earnings data from the Annual Survey of Hours and Earnings (ASHE). Our results are based on the sample period 1992-2016.

Existing research on immigration and wages has tended to focus on the impact of immigration on natives. See for example Altonji and Card (1991). This is becuase when designing immigration policy that is what natives most care about. So what does this body of research tell us? The balance of existing research suggests that the share of immigrants in the workforce has had little or no impact on the pay rates of natives. Nevertheless, there is a continuing controversy, exemplified by the influential works of Borjas (2003) and Card (2005).

In an earlier paper, Card (1990) examined the impact of the Mariel Boatlift of Cubans into the Miami labour market and found little impact on the wages of natives. Borjas (2003, 2005) and Borjas and Katz (2007) argued that such an analysis gives a misleading impression because regional labour markets are not self-contained. Thus, as immigrants move into a region, natives move out, thereby attenuating local wage effects. So he considers the impact of immigrants on wages in national age/education groups and finds a significant impact on wages in the United States: Borjas concludes that an immigrant inflow of 10 percent of the labour force lowers the wages of natives by 3 or 4 percent.

But other research that takes account of native mobility is unable to confirm the Borjas (2003) results. For example, Card and DiNardo (2000) and Card (2005), in an analysis of U.S. cities, finds first that increases of immigrants into localities have generated significant rises in the proportion of low-skilled workers (high school dropouts) and second, that these large shifts in the proportions of the low-skilled have had minimal effects on the low-skill wage relative to their effect on the high-skill wage. ${ }^{2}$ Ottaviano and Peri (2012), who build and extend the Borjas framework, also conclude that immigration has had a small impact on the wages of native workers. More recently Borjas (2017)) has written a reappriasal of Card's study of the Mariel Boatlift and argues that if one carefully compares the skill levels of Cuban immigrants to the equivalent low skilled immigrants in Miami, one can find a wage elasticity of -0.5 to 0.15 percent. 
Evidence for the United Kingdom is consistent with the findings of Card (2005), suggesting that the impact of immigration on the wages of natives is minimal (see Dustmann et al. $(2005,2013)$ and Manacorda et al. (2012), for example). Both Ottaviano and Peri (2012) and Manacorda et al. (2012) conclude that the more recent immigration has the biggest negative effect on the wages of previous immigrants.

The contribution of this paper to the existing literature is twofold.

First, it considers whether EU migrants have a different impact on wages when compared to non-EU migrants. There are reasons to suspect that EU immigration is different because EU immigrants tend to be more educated, yet more likely to find employment in low skilled jobs (See Saleheen and Shadforth 2006). This aspect has not been explored previously, and we think the answer to this question could be a useful input into future British migration policy, post the Brexit vote on 23 June 2016.

Second, while previous research has concentrated on looking for wage effects of immigration among the low-skilled, where skill levels are defined in terms of education, this paper makes a novel contribution to the literature by considering skills as measured by occupation. We think our approach of segmenting the labour market by occupations is more suited to the study of immigration because when it comes to the measurement of education levels of migrants, one finds that it is often tricky to accurately compare education qualifications across countries, given the different education systems and arguably differences in the quality of education. For example, is the International Baccalaureate a higher, lower or similar qualification to A Levels? Furthermore, for a variety of reasons, many immigrants who come to the United Kingdom with high qualification levels work in low-skill occupations. As such, an analysis that depends on using education levels to partition the data may give a misleading read on how immigration is affecting wages. One advantage of our approach is that it focuses the analysis on the various occupational groups in the labour market, such as plumbers, agricultural workers, nurses, waiters, etc., which has been the subject of much of the public discussion.

Some occupations see a very heavy influx of immigrants. For example, in Britain, over 30 percent of health professionals (doctors and dentists) are immigrants, compared with around 5 percent of those in skilled agricultural trades (farmers and gardeners). A priori, it seems unlikely that a substantive rise in immigration in a particular region and occupation has had absolutely no impact on pay in that region and occupation. Our purpose is to find out more about this.

While there is a great deal of anecdotal discussion on the impact of immigration in specific occupations like agriculture and construction, we feel it would be helpful to present some harder data on this subject. For this reason, section 2 of this paper is about occupations.

Section 2 sets out the key facts about immigration from the EU and elsewhere, and how immigration and wage trends have evolved across occupations over time. Section 3 describes the theoretical model, which underpins our expected relationship between wages and immigration. Section 4 moves on the the empirical analysis of this relationship. The key challenge here, as in much of the literature, is that of identification as immigration is unlikely to be exogenous to wages. We follow the approach of Card (2001) and Cortes 
(2008), among others, by instrumenting immigration by creating a counterfactual profile for immigration across regions and occupations by using the historic settlement patterns of immigrants from different countries. ${ }^{3}$ Section 4 considers differences among EU and non-EU migrants. Section 5 concludes.

\section{Immigration across occupations: some facts}

Immigration to the United Kingdom has risen dramatically over the past two decades. This can be seen clearly from the Figures below. Figure 1, panel a, shows that according to the official migration statistics, the net inflow of immigrants to the United Kingdom each year has risen from around 50,000 individuals in 1995 to over 300,000 in 2016. Data on net immigration for the full calendar year of 2016 is still not available, but the latest data for the year to June 2016 shows that immigration has reached a record high of 335,000 . The gross inflow has grown as well, but it has increased by more than the gross outflow, and as a result, the net inflow of immigrants has risen dramatically since the mid-1990s. Figure 1, panel b, shows how the stock of immigrants-defined as foreignborn workers-has become a larger share of the U.K. working age population. Having been stable at around 8 percent between 1984 and 1995, it has grown to around 22 percent by 2016. And the share of "new" immigrants - those who arrived in the UK in the previous two years-has also increased since 1995, peaking just before the financial crisis at $1.4 \%$ in 2007 , falling back a little in the post-crisis years, to around $0.8 \%$, before picking

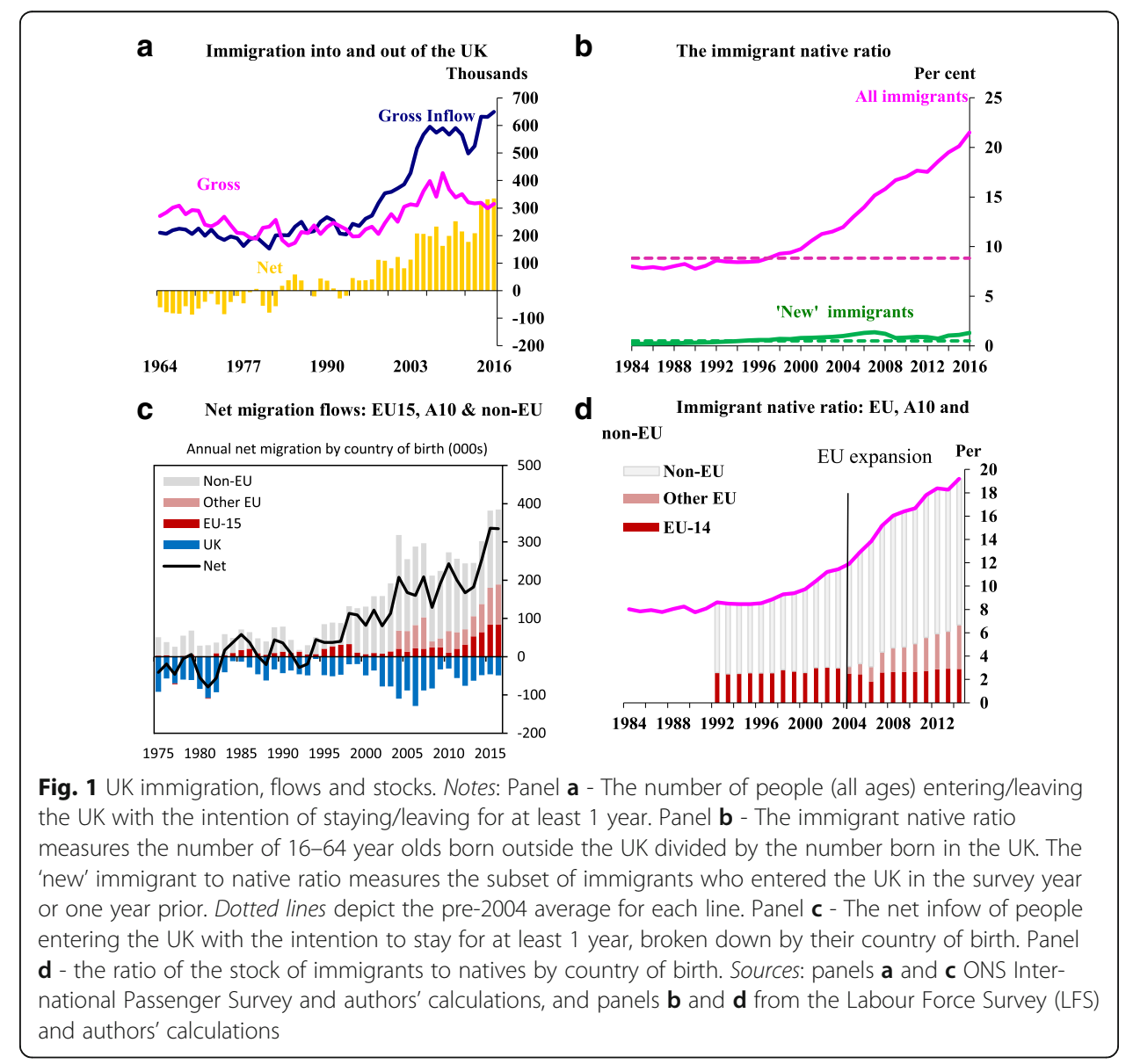


up again to reach $1.3 \%$ in 2016 . The share of new immigrants could be interpreted as an alternative measure of the flow of immigration.

Given the recent interest in immigration from the EU, Fig. 1c and d set out how immigration from this sub-group has changed. Immigration from the EU-14 countries has been pretty stable in recent decades, with immigration from the new EU member states, the so called A10 countries - Czech Republic, Cyprus, Estonia, Slovakia, Slovenia, Lithuania, Hungary, Poland, and Malta - rising recently. That rise is undoubtedly related to the expansion of the EU to include the new A10 countries in 2004. Until the mid-1990s it was standard practice for all EU countries to grant free movement of labour to new EU member states at the time they joined the EU. But the 2004 expansion saw many countries change their approach and delay labour market access - the UK, Ireland and Sweden were the only EU-15 countries to grant full labour market access to the new A10 countries in 2004. Other countries delayed access by 26 years. Later when Bulgaria and Romania joined the EU in 2007, the UK changed its approach and opted - like other high income EU countries - to delay labour market access of nationals from these two countries until 2014. While the immigration policy of the UK and other countries in Europe, undoubtedly played a role in shaping the trends in immigration, macro factors such as the relative economic growth of the UK compared to Europe would also have played an important role.

Whatever the determinants, Fig. 2 shows that this new wave of immigration looks to have had a noticeable downward impact on the average wages of EU immigrants in the UK around the year of Accession, some of which will undoubtedly reflect the occupations these immigrants move into and the potentially lower reservation wages of these workers.

This rise in immigration to the United Kingdom in recent years has been well documented in past studies. But very little has been said about the occupations in which immigrants end up. In this section, we explore the key facts about immigration across occupations. In particular, we document which occupations attract the most immigrants and whether this has changed over time. We also document the trends in wages in the different occupations.

To consider how immigration and wages have changed in each occupation one needs a consistent definition of occupations over time. One challenge is that the British Standard

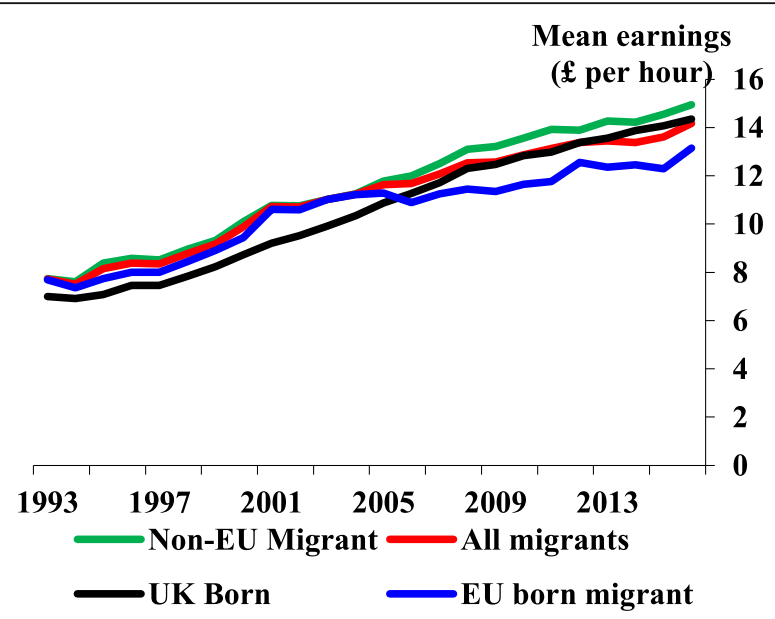

Fig. 2 Hourly Earnings for immigrants and non-immigrants. Source: Labour Force Survey (LFS) and authors' calculations 
Occupational Classification (SOC) changed from SOC 1990 to SOC 2000 at the turn of the century. The aim of this change was to better measures the tasks done in each occupation, but it created a discontinuity for the study of changes across occupations in the last few decades. We deal with this discontinuity by transforming, or converting, the old SOC 1990 classification into the new SOC 2000 classification - that is by creating a consistent definition of occupations throughout our dataset. Details of the methodology used are set out in the Appendix 1.

\subsection{Immigration across occupations}

Which occupations attract the most immigrants? Figure 3a shows the ratio of immigrants to natives in each broadly defined occupation group - measured at the SOC 2000 1-digit level. It shows that the immigrant-native ratio varies considerably across broad occupations. It is highest for elementary workers (for example, cleaners and labourers) and operatives (clothing cutters, plastic wood and machine operatives): in these occupations 1 in 3 workers are immigrants. The immigrant native ratio is also high for professional workers (e.g. engineers): 1 in 5 workers are immigrants. And the ratio tends to be low in administrative occupations (secretaries, call centre staff); 1 in 10 are immigrants. Although the immigrant to native ratio is lowest here, it should be noted that around 15\% of all immigrants in 2014-2016 were in administrative occupations. Most immigrants tend to end up in professional and elementary occupations.

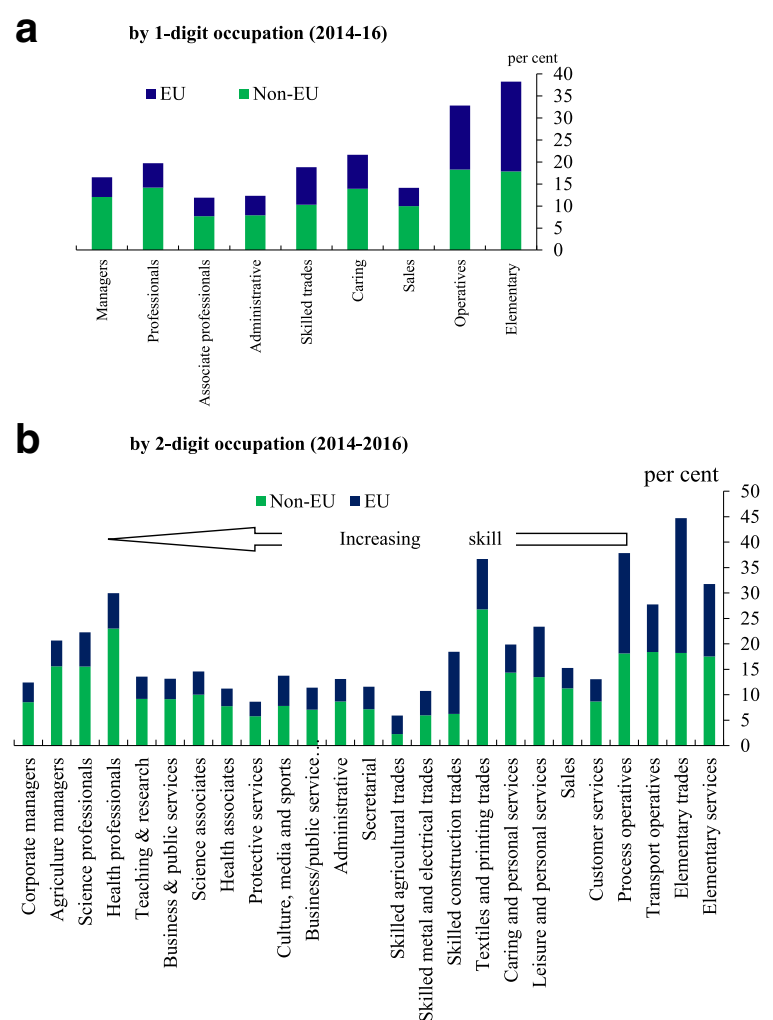

Fig. 3 Immigrant native ratio by 1 and 2 digit occupation. Source: Labour Force Survey (LFS) and authors' calculations 
Figure 3, panel a, also shows the split by immigrants from the EU and non-EU countries. What stands out here is that EU migrants are most prominent in the low skilled Elementary and Operative occupations, which include taxi drivers, cleaners and labourers. Further examples of the types of jobs that fall into each of these occupations are presented in Table 8 of Appendix 1.

Figure 3, panel $\mathrm{b}$ shows the immigrant-native ratio at a more detailed, 2-digit level. The picture is now one of greater variability, with no strong patterns. A very high proportion of U.K. health professionals are immigrants. There is also a high share of immigrants in textiles (tailors), process operatives (plastic process operatives) and elementary trades (labourers). A lower share of immigrant workers in in protective services (for example as security guards) and skilled agricultural trades (farmers).

Earlier it was noted that overall immigration to the United Kingdom has risen rapidly since the middle of the 1990s. An important question here is whether that rise has affected all occupations proportionately or has it been more heterogeneous?

We consider how the immigrant-native ratio across occupation has evolved over four sub time periods - 92-94, 04-06, 08-10 and 2014-16. These periods reflect the start and end of our sample, the period just after EU Accession and the aftermath of Global Financial Crisis. Figure 4 makes evident that immigration has grown across most occupations, with the sharpest rise in the lowest skill occupations (Elementary jobs). To give a sense of this relativity, the immigrant-native ratio for managers grew by around 7 percentage points between 1992-94 and 2014-16, whereas it grew by 30 percentage points in elementary jobs over the same period. These changes mean the pattern of immigration across occupations has changed dramatically over the past two decades. In the early 1990s, we described the pattern of immigration across occupation as having a shallow Ushape, being high at the top and bottom skill levels than in middle skilled occupations. ${ }^{4}$ But in recent years, the pattern of immigration across occupations has become more linear - lower shares in high skilled jobs and higher shares in lower skilled jobs.

Figure 5 breaks the rise in immigration down into immigration from the $\mathrm{EU}$ and non-EU. Figure $5 \mathrm{~b}$ shows that the pace of rise in immigration from outside of the EU appears to have been steady over time, but growing fastest in low skilled jobs (Elementary and Operatives). In contrast the EU immigrant-native ratio appears to have been

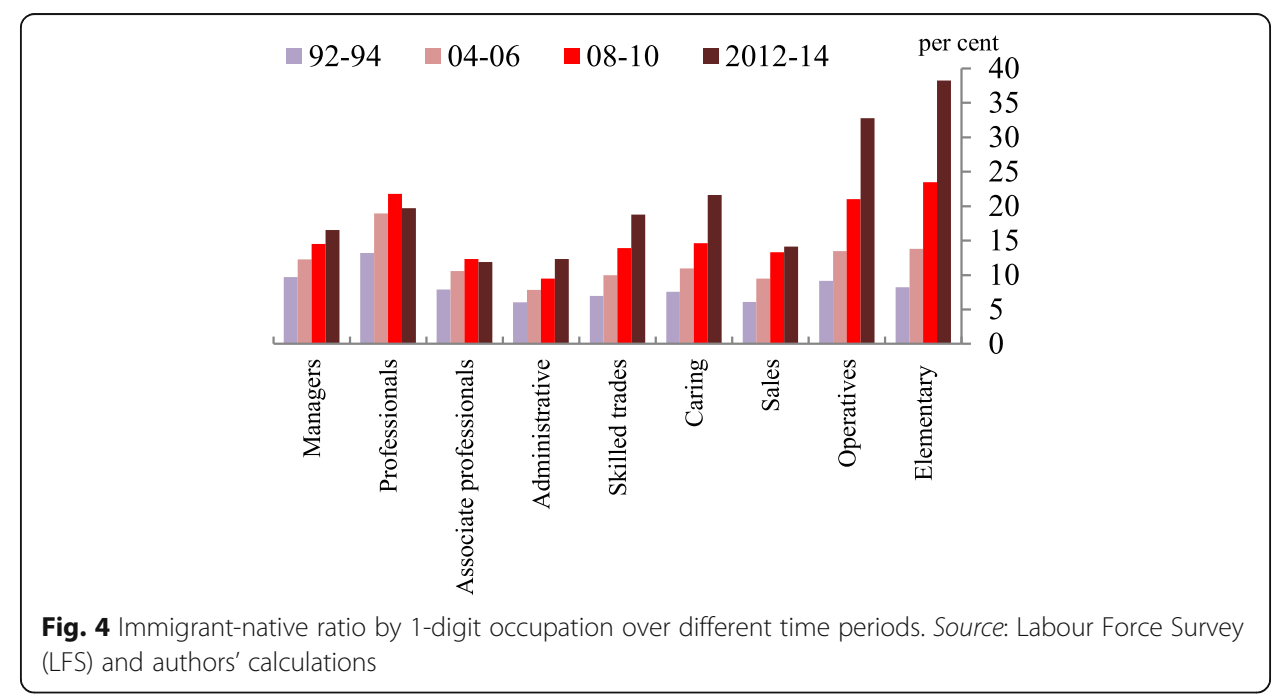




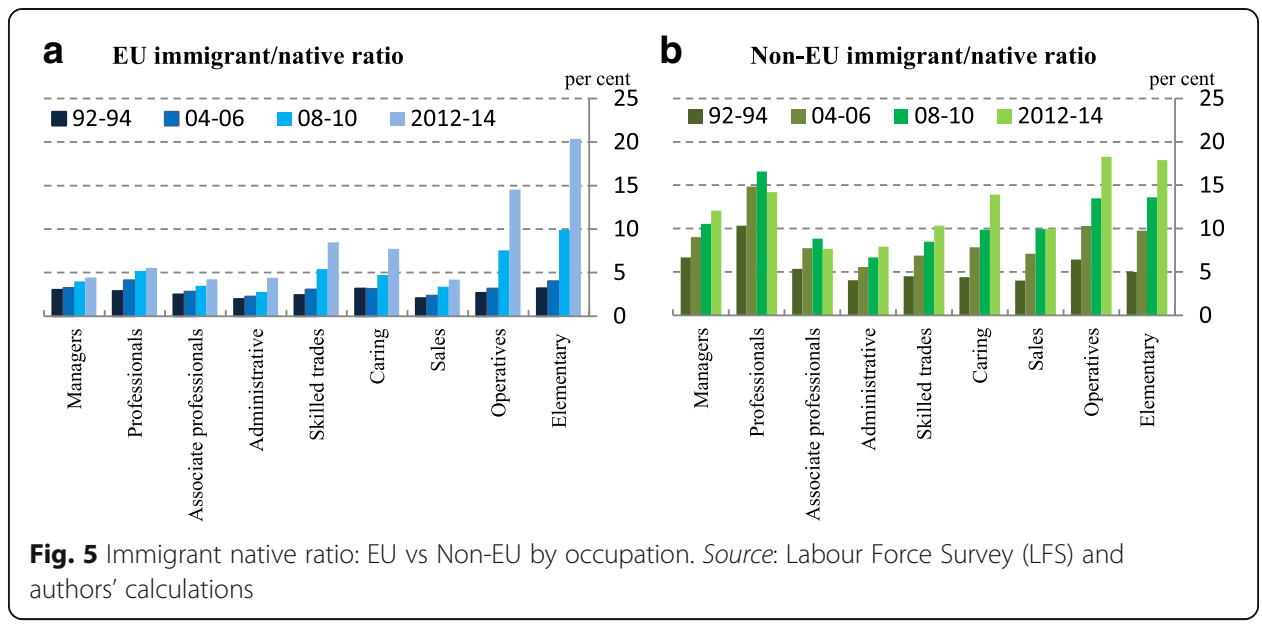

rather stable until 2006, rising rapidly thereafter by markedly more in low skilled jobs (Fig. 5a).

To summarise, the pattern of immigration across occupations has changed noticeably over time and across occupations. In the early 1990s immigration was spread across high and low skilled occupations. In 2014-2016, there was a greater abundance of immigration in low skilled jobs, particularly from EU countries. These changes in the structure of immigration across occupations are, at least in part, related to the expansion of the European Union to include many Central and Eastern European countries in 2004 and the immigration policy of the UK that allowed workers from these countries to work in the UK. The Euro Area crisis and related macro weakness in Europe will also be a key push factor in driving workers to the UK, where the labour market prospects were relatively better at the time (See Carney (2015)). An important question addressed in this paper is whether immigrants from the EU have a different impact on wages than non-EU immigrants.

\subsection{Wage movements across occupations}

This section documents the changes in pay across occupations in recent years. Pay is defined here as the nominal hourly wage rate of full-time workers as captured by the Annual Survey of Hours and Earnings (ASHE) - a comprehensive survey of employers (see Appendix 1 for more details). ${ }^{5}$ Figure 6 shows how the average wage in each occupation, has evolved relative to the average wage across all occupations. ${ }^{6}$ The horizontal line at 1 is a benchmark that illustrates the average wage rate in an occupation across all regions. Occupations where the plots are above this benchmark of 1 are occupations where wages are higher then the average. Similarly occupations where the wage plots are below 1 are those where the average worker earns below the national average. Two things stand out. First, high-skilled jobs (managers, professionals) earn more than the average wage, and low-skilled jobs (operatives and elementary occupations) earn below the average. Managers earn nearly 1.5 times the average wage, and Elementary workers earn around $50 \%$ below the average wage. Second, we see that relative wages have fallen in some occupations and have been flat to rising for other groups. That relative wages have increased for some groups and decreased for others is a well-documented fact in the literature on U.K. wage inequality (see, for example, Machin (2003)). For example, the relative wages 


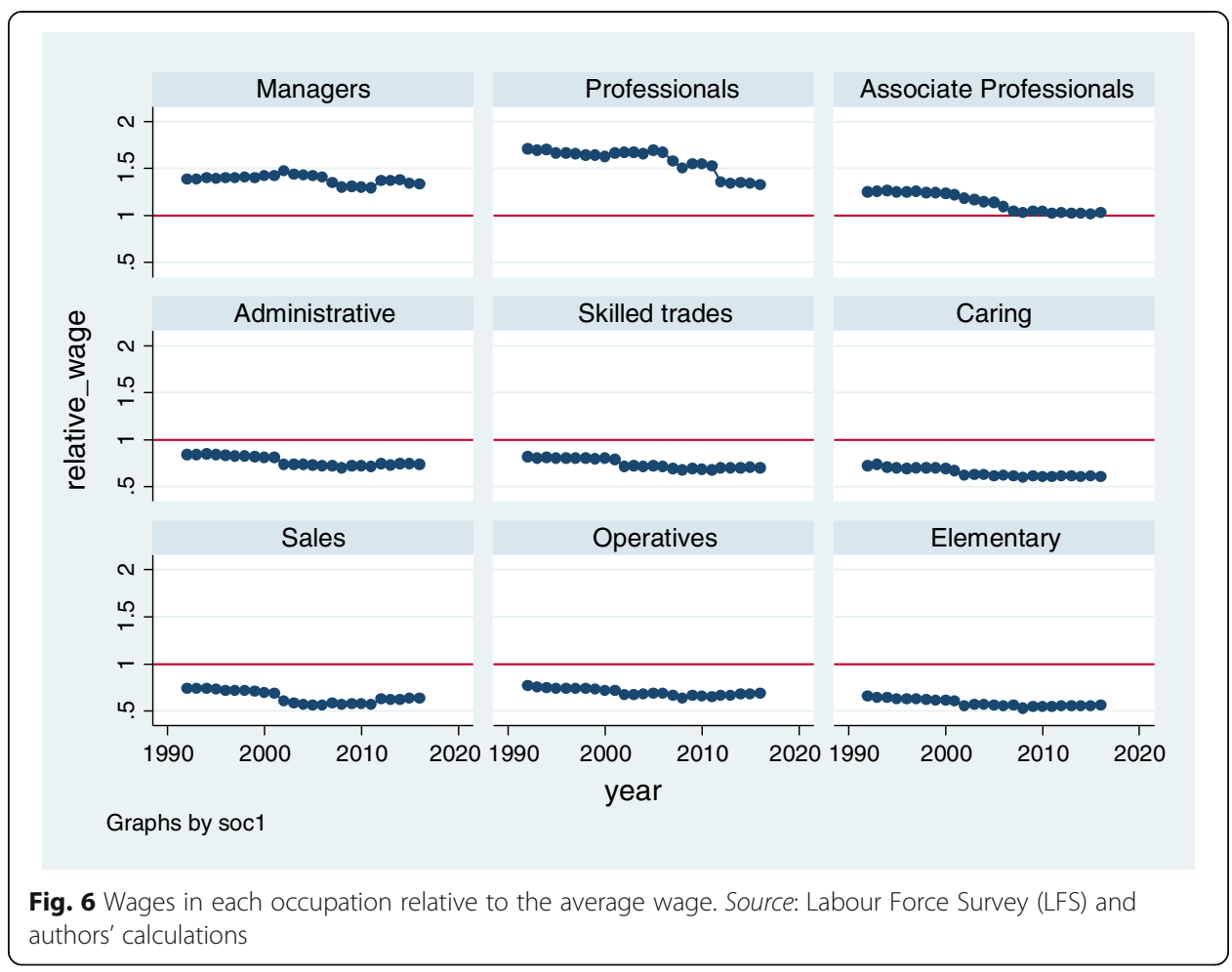

for Professionals and Associate Professionals (which included teaching and research staff) has fallen noticeably over time, with smaller declines over time seen in Sales and Elementary occupations. There has been more stability in wages for other skills such as for Managers and Administrative staff. So there has been some heterogeneity in changes in relative wages across occupations.

This section has documented some new stylised facts about how wages and immigration vary across different occupations. It finds that immigrants in recent years are most pominant in low-skill occupations, with a significant presence amongst high-skilled occupations as well. And while the immigrant-native share has continued to increase across all occupations since the mid-1990s, in recent years the rise has been greatest in low-skill occupations. The concentration of EU immigrants in low- skilled jobs has increased in recent years. Low-skill occupations, of course, pay wages that are below the average wage rate. But there has been some heterogeneity in the evolution of relative wage rates across occupations over time.

\section{Theoretical background}

Since we are going to undertake an empirical analysis of occupational wage changes, it is helpful to develop a theoretical framework to enable us to interpret the results. This model builds on the frameworks set out in Layard, Nickell and Jackman (1991).

Suppose each region has an aggregate production function of the form

$$
Y_{r t}=F\left(N_{1 r t}, \ldots, N_{I r t}, s_{1 r t}, \ldots, s_{I r t}, K_{r t}, A_{r t}\right)
$$

where $Y$ =output, $N_{i}=$ employment in occupation $i, i=1 \ldots \mathrm{I}, s_{i}=$ share of immigrants in occupation i, $K=$ fixed capital, $A=$ technical change factor, $r=$ region, and $t=$ time. The role of the share of immigrants is to capture the possibility that immigrants are more 
or less productive than natives or, at least, are thought to be so by the owners of firms. The demand for regional output is given by

$$
Y_{r t}=\left(P_{r t} / P_{t}\right)^{-\eta_{r t}} D_{r t}
$$

Where $P_{r t}=$ the price of regional output, $P_{t}=$ the aggregate price level, and $D_{r t}=$ the regional demand index, which captures the extent to which aggregate demand in a particular region may rise or fall. If the occupational wages are $W_{i}$ and $K$ and $A$ are predetermined, employment is determined by solving

$$
\max _{N_{i}, P, Y} P_{r t} Y_{r t}-\sum_{i=1}^{I} W_{i r t} N_{i r t}
$$

subject to (1) and (2). Note that, within occupations, we assume that firms are unable to pay different wages to natives and immigrants, an assumption consistent with current U.K. anti-discrimination legislation. ${ }^{7}$

The first-order conditions are given by

$$
\left(1-\frac{1}{\eta_{r t}}\right) p_{r t} F_{i}\left(N_{1 r t}, \ldots, N_{I r t}, s_{1 r t}, \ldots, s_{I r t}, K_{r t}, A_{r t}\right)=w_{i r t}
$$

where $\mathrm{i}=1, . . \mathrm{I}$, and $p_{r t}=P_{r t} / P_{t}, w_{r t}=W_{i r t} / P_{t}$ are real prices and real wages, respectively. If we make a log-linear approximation of the I equations in (3) and solve for $n_{i r t}=\ln$ $N_{i r}$, all i, we have

$$
n_{i r t}=\alpha_{0}-\alpha_{1} \ln w_{i r t}+\sum_{\substack{j=1 \\ j \neq i}}^{I} \alpha_{1 j} \ln w_{j r t}-\alpha_{2} s_{i r t}+\sum_{\substack{j=1 \\ j \neq i}}^{I} \alpha_{2 j} s_{j r t}+\alpha_{3} \ln \left(p_{r t}\left(1-\frac{1}{\eta_{r}}\right)\right)+\alpha_{4} \ln K_{r t}+\alpha_{5} \ln A_{r t}+v_{i r t},
$$

where $i=1, \ldots$. I. Note that we have written these I equations with identical coefficients, with any differences absorbed into the error. This "assumption" is ultimately dropped in our empirical analysis when we estimate models that differ across occupations.

Suppose the cross effects are not large and may be approximated by

$$
\sum_{\substack{j=1 \\ j \neq i}}^{I}\left(\alpha_{1 j} \ln w_{j r t}+\alpha_{2 j} \ln s_{j r t}\right)=\alpha_{i r}^{\prime}+\alpha_{r t}^{\prime}+\alpha_{i t}^{\prime}+v_{i r t}^{\prime}
$$

So we end with a simple regional-occupation labour-demand equation of the form

$$
n_{i r t}=\alpha_{i r}+\alpha_{r t}+\alpha_{i t}-\alpha_{1} \ln w_{i r t}-\alpha_{2} s_{i r t}+v_{i r t}^{1}
$$

where $\alpha_{3} \ln \left(p_{r t}\left(1-\frac{1}{\eta_{r t}}\right)\right)+\alpha_{4} \ln K_{r t}+\alpha_{5} \ln A_{r t}$ are absorbed into $\alpha_{r t}$. Then the cross effects, output prices, capital, and technical change are all captured by the occupation/region effects, $\alpha_{i r}$; the region/time effects, $\alpha_{r t}$; and the occupation/time effects, $\alpha_{i t}$. The impact of the immigrant share is negative $\left(\alpha_{2}>0\right)$ if immigrants are less productive than natives, and positive $\left(\alpha_{2}<0\right)$ if they are more productive.

Turning to region/occupation labour supply, we suppose an equation of the form

$$
n_{i r t}=\gamma_{i r}+\gamma_{r t}+\gamma_{i t}+\gamma_{1} \ln w_{i r t}-\gamma_{2} u_{i r t-1}+\gamma_{3} s_{i r t-1}+\gamma_{4} X_{i r t}+v_{i r t}^{2}
$$

where $\mathrm{u}$ is the unemployment rate and $\mathrm{X}$ are other exogenous variables. The idea here is that labour is attracted into region $r$ if wages are higher than those elsewhere 
(captured in the occupation/time effect, $\gamma_{i t}$ ), if relative unemployment is lower, and if high immigrant proportions tend to attract mobile workers $\left(\gamma_{3}>0\right)$. If immigrants have a lower reservation wage than natives, then labour supply will be higher, given wages, when the share of immigrants is higher. This is another reason why $\gamma_{3}$ may be positive. It is, of course, possible that high immigrant proportions are a disincentive to move to work in region $r$ and that immigrants have higher reservation wages than natives $\left(\gamma_{3}\right.$ $<0)$. Similarly, the immigrant proportion in region $r$ depends on the attractiveness of the region; thus,

$$
s_{i r t}=\beta_{i r}+\beta_{r t}+\beta_{i t}+\beta_{1} \ln w_{i r t}-\beta_{2} u_{i r t-1}+\beta_{3} s_{i r t-1}+\beta_{4} X_{i r t}+v_{i r t}^{3}
$$

The structure is similar to the labour supply equation, (5), although $\beta_{3}>0$ is almost certainly positive because it is known that immigrants have a tendency to cluster.

Our analysis concentrates on wage movements, so we consider the wage equation obtained by using (5) and (6) to eliminate $n_{i r t}, s_{i r t}$ from (4). This yields an equation of the following form:

$$
\ln w_{i r t}=\omega_{i r}+\omega_{r t}+\omega_{i t}+\omega_{2} u_{i r t-1}-\omega_{3} s_{i r t-1}+\omega_{4} X_{i r t}+\omega_{i r t}
$$

In particular, the coefficients on $u$ and $s$ are $\left(\gamma_{2}+\alpha_{2} \beta_{2}\right) /\left(\gamma_{1}+\alpha_{1}+\alpha_{2} \beta_{1}\right)$ and $-\left(\gamma_{3}\right.$ $\left.+\alpha_{2} \beta_{3}\right) /\left(\gamma_{1}+\alpha_{1}+\alpha_{2} \beta_{1}\right)$, respectively. Overall, occupation/region wages are driven by basic factors such as regional productivity, regional labour market slack, regional product demand, national occupation demand, and unchanging occupation/region characteristics. All these are captured by the three types of interaction dummies, $\omega_{i n} \omega_{r t}$, and $\omega_{i t}$. The impact of the lagged immigrant share on pay is negative if $\left(\gamma_{3}+\alpha_{2} \beta_{3}\right)>0 . \gamma_{3}$ is positive, if occupation/region labour supply is enhanced by the presence of existing immigrants, or if immigrants have a lower reservation wage than natives, and, since $\beta_{3}$ is almost certainly positive, as we have already noted, $\alpha_{2} \beta_{3}$ is positive if immigrants are, or are thought to be, less productive than natives in the same occupation. So these are the conditions that will tend to generate a negative impact of the pre-existing immigrant share on wages. Finally, note that we are taking account of the feedback effect of wages on the immigrant share by substituting out the current immigrant share using equation (6).

Turning to the unemployment effect, this will be positive if $\left(\gamma_{2}+\alpha_{2} \beta_{2}\right)>0 . \gamma_{2}$ and $\beta_{2}$ are almost certainly positive, because this depends on the uncontroversial notion that high unemployment makes regions less attractive to potential employees. $\alpha_{2}$ is positive if migrants are less productive than natives, as noted above. Overall, we would expect this unemployment effect to be positive. It is worth commenting on how this relates to the standard negative "wage curve" effect of unemployment on wages. This has been absorbed into the region/time dummy, which already captures local labour market slack. What remains is the second-round effect, whereby local occupation-specific unemployment makes the region less attractive, reducing local occupational labour supply and raising pay.

So equation (8) is the basis for our empirical investigation. The analysis in this section has been fundamentally static. In practice, because of adjustment costs we would not expect instantaneous adjustment, so we also consider dynamic versions of (8). Finally, equation (8) has the same coefficient for all occupations, any differences being absorbed into the error. To pursue this further, we also investigate models of the same form as (8), except we estimate them separately for different groups of occupations. 


\section{Data and results}

The purpose of this section is to investigate whether the lagged immigrant-native ratio in a particular region and occupation has any impact on the average pay rate of that region and occupation. We do this by estimating various forms of a standard reduced form wage equation across a panel of regions and occupations (see Pesaran and Smith (1995) and Wooldridge (2002)).

This equation is derived from our simple theoretical model of labour demand and labour supply described in Section 3. The key model equation that informs our empirical specification is 8 . This equation postulates that wages in any occupation and region are derived by basic factors such as regional productivity, regional labour market slack, regional product demand, national levels of demand and unchanging occupation and region characteristics. Wages will also respond to changes in the supply of labour, which are in part captured by the share of immigrants in the workforce - the main variable of interest for this paper. Occupational and regional wages are also sensitive to changes in the unemployment rate of that region and occupation.

The primary sources of data for our analysis are the British Labour Force Survey (LFS) and the Annual Survey of Hours and Earnings (ASHE). ${ }^{8}$ To estimate these equations we use a panel dataset that we have created in which each observation covers three dimensions: region, occupation, and time. This panel contains information on 11 U.K. Government Office Regions and 25 occupations, based on the 2-digit SOC 2000 occupational classification, over 25 years (1992-2016). ${ }^{9}$ Based on this level of disaggregation, our dataset has a maximum of $6875(=25 \times 11 \times 25)$ observations.

Each observation in our dataset relates to a particular region, occupation, and year cell. For each cell, we have information about the hourly wage, the unemployment rate, the ratio of immigrants to natives, the ratio of EU immigrants, as well as controls for age and education.

We follow the literature and define an immigrant on the basis of their country of birth - if they are born outside the UK, they are classified as an immigrant. Similarly if they are born in the EU they are classified as EU immigrants, with those born outside grouped into non-EU immigrants.

The inclusion of age and education controls in our specification follows from our theoretical model to capture the average level of productivity across region and occupation cells. Theoretical models of human capital and growth are built around the hypothesis that the knowledge and skills embodied in humans directly (e.g. through their education) raises productivity and increase an economy's ability to develop and to adopt new technologies (Lucas, 1988). The age controls are defined as the average age of natives and the average age of immigrants. There are four education controls, each measuring the share of the native population native in each region, occupation cell that have completed a university or college degree, a secondary school education, those who have not completed secondary school, and those who are students. These qualifications are derived according to the length of time individuals have spent in full-time education because of the difficulties described above of not having comparable data on the level of qualifications across countries. ${ }^{10}$ People still in full-time education are classified as students, those who left full-time education before 16 are classified as having incomplete schooling, and those who left after age 21 as having a degree. Individuals who left 
full-time education between the ages of 16 and 20 are classified as having completed secondary school.

Table 1 shows the mean and standard deviations for these key variables over all time periods, regions, and occupations. Over our entire dataset the average hourly wage is $£ 11.18$, the average unemployment rate is 5.1 percent, and the average immigrantnative ratio is 13.2 percent. Most of these immigrants arrived more than two years ago-the ratio of old immigrants to natives is 12.1 percent; the ratio of new immigrants to natives is just below 1 percent. Over the full sample period, two thirds of immigrants are from non-EU countries, with one third being from the EU. Although we will come on to show that the share of EU immigrants has increased over time.

\subsection{Pooled specification}

We begin with a 'pooled' estimation of our key equation that describes how wages vary with the share of immigrants. The pooled specification assumes that the impact of immigration on wages is identical across all occupations. Later, we relax this assumption and allow the impact of immigration on wages to differ by occupation.

In our key equation, the dependent variable refers to log real wages. In practice, we use $\log$ nominal wages with the price normalization being absorbed into the region/ time dummies. The main independent variable, which follows from equation 8 above, is the lagged ratio of the number of immigrants and the number of natives in a particular occupation and region cell. Figure 7 provides a sense of the degree of variation in the immigrant-native ratio across each of the 11 regions, through the aid of a box plot.

Table 1 Means of variables

\begin{tabular}{|c|c|c|}
\hline & Mean & Standard deviation \\
\hline \multicolumn{3}{|l|}{ Dependent variable } \\
\hline$W_{\text {irt }}\left(\varepsilon^{\prime} S\right)$ & 11.18 & 5.13 \\
\hline In $W_{\text {irt }}$ & 2.32 & 0.42 \\
\hline \multicolumn{3}{|l|}{ Independent variables } \\
\hline immigrant/native ratio irt & 0.132 & 0.200 \\
\hline new immigrant/native ratio irt & 0.009 & 0.015 \\
\hline old immigrant/native ratio irt & 0.124 & 0.189 \\
\hline EU immigrant/native ratio irt & 0.043 & 0.067 \\
\hline non-EU immigrant/native ratio irt & 0.090 & 0.145 \\
\hline unemployment rate ${ }_{\text {irt }}$ & 0.051 & 0.039 \\
\hline \multicolumn{3}{|l|}{ age controls } \\
\hline mean immigrant age irt (years) & 39.71 & 4.29 \\
\hline mean native age irt (years) & 39.76 & 3.15 \\
\hline \multicolumn{3}{|l|}{ skill controls } \\
\hline \multicolumn{3}{|l|}{ share of native population } \\
\hline - with degree & 0.185 & 0.211 \\
\hline - with completed school & 0.618 & 0.151 \\
\hline - still in education & 0.025 & 0.039 \\
\hline - with incomplete schooling & 0.171 & 0.117 \\
\hline
\end{tabular}

Sources: LFS and ASHE/NES. 


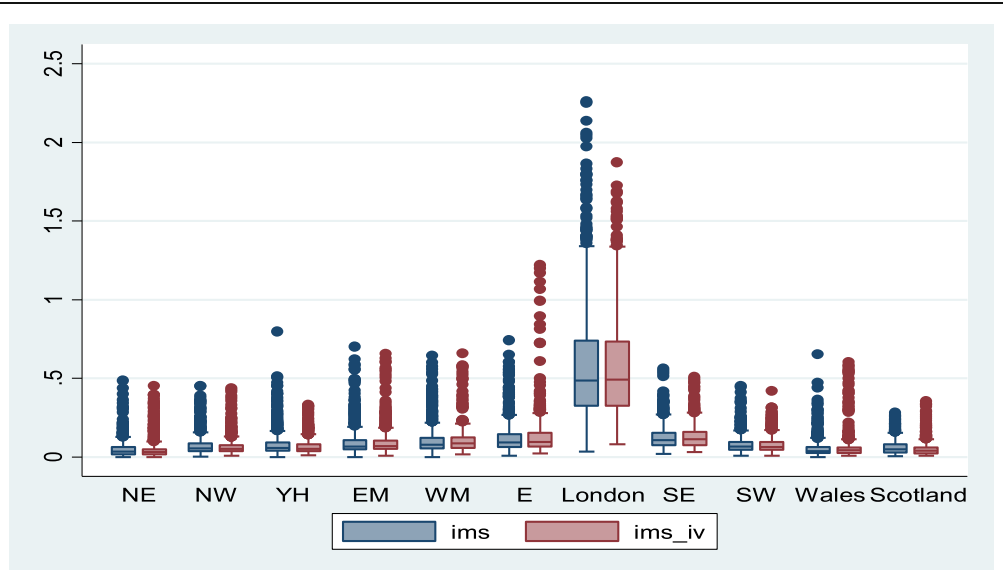

Fig. 7 The variation in the immigrant native ratio, and the instrumented immigrant native ratio: by region. Notes: The variable 'ims' - measure the ratio of immigrants to natives in each region, occupation and year cell. The variable 'ims_iv' is the instrument used for the immigrant native ratio that is created using historic settlement patterns. A full description of this method is set out in Appendix 1. Source: Labour Force

The question of focus is: does the lagged immigrant-native ratio have any impact on wages? In Table 2, we present the basic results. The table shows that the immigrant proportion has a significant negative impact on pay. The scale of this impact suggests that if the proportion of immigrants working in a particular occupation rises by 10 percentage points, the occupational wage falls by around $0.2-0.3$ percent. This is a relatively small effect.

Table 2 The Impact of Immigration on Wages, Static Model

\begin{tabular}{|c|c|c|c|c|c|c|}
\hline & \multicolumn{6}{|c|}{ Dependent Variable, $\operatorname{Ln} W_{\text {irt-1 }}$} \\
\hline & (1) & (2) & (3) & (4) & (5) & (6) \\
\hline & Not weighted & Weighted & $\begin{array}{l}\text { Weighted, } \\
\text { robust S.E.S }\end{array}$ & $\begin{array}{l}\text { Not } \\
\text { weighted }\end{array}$ & Weighted & $\begin{array}{l}\text { Weighted, } \\
\text { robust S.E.s }\end{array}$ \\
\hline & OLS & & & IV & & \\
\hline \multicolumn{7}{|l|}{ Panel a: Full Sample } \\
\hline 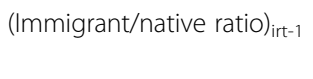 & $\begin{array}{l}-0.023^{* * *} \\
(0.008)\end{array}$ & $\begin{array}{l}-0.034^{* * *} \\
(0.007)\end{array}$ & $\begin{array}{l}-0.034 \\
(0.040)\end{array}$ & $\begin{array}{l}-0.047^{*} \\
(0.029)\end{array}$ & $\begin{array}{l}-0.082^{* * *} \\
(0.021)\end{array}$ & $\begin{array}{l}-0.082 \\
(0.091)\end{array}$ \\
\hline Unemployment rate ${ }_{\text {irt-1 }}$ & $\begin{array}{l}0.067^{*} \\
(0.036)\end{array}$ & $\begin{array}{l}0.090^{*} \\
(0.038)\end{array}$ & $\begin{array}{l}0.090^{*} \\
(0.050)\end{array}$ & $\begin{array}{l}0.05 \\
(0.037)\end{array}$ & $\begin{array}{l}0.042 \\
(0.040)\end{array}$ & $\begin{array}{l}0.42 \\
(0.090)\end{array}$ \\
\hline Sample Size & 6,468 & 6,468 & 6,468 & 6,454 & 6,454 & 6,454 \\
\hline Adjusted $R^{2}$ & 0.993 & 0.996 & 0.996 & 0.993 & 0.996 & 0.996 \\
\hline
\end{tabular}

Notes:

${ }^{a}$ Equations in column (1), (2) and (3) are estimated using ordinary least squares (OLS), with columns (4), (5) and (6) being estimated using instrumental variables, where the lagged immigrant native ratio is instrumented using a counterfactual that is based on the historic settlement enclave of immigrants.

b Standard errors are reported in parenthesis; those in columns (3) and (5) are heteroskedasticity-robust, clustered over the 275 regions-occupation groups.

c In specifications 2, 3, 5 and 6 we weight each cell by its employment.

Each equation also contains age controls (mean immigrant age, mean native age), skill controls (share of native population with degree, with completed school, still in education) and a full set of region/year, occupation/year and region/occupation interaction dummies.

${ }^{d} t=$ time (25 years, 1992-2016), $\mathrm{i}=$ occupation (25 2-digit occupations), $r$ = region (11 Government Office Regions). This implies a maximum of 6875 ( $25 \times 25 \times 11)$ observations. The table shows fewer observations because some cells have have missing information.

e $*^{* *}=$ significance at $1 \%$ level; ${ }^{* *}=$ significance at $5 \%$ level; ${ }^{*}=$ significance at $10 \%$ level.

Sources: LFS and ASHE/NES. 
Given the ongoing controversy in the literature of the impact of immigration on wages, it is important to ask, how reliable are these findings? The reliability of these results depends on the accuracy of the data and the appropriateness of the method of estimation. ${ }^{11}$ A common problem faced by most empirical studies that try to estimate the impact of immigration on wages is that the increase in immigration to any particular region or occupation is not clearly exogenous. In particular, if immigrants are likely to be attracted to areas with strong demand, then any empirical relationship relating the immigrant-native ratio to wages will tend to pick up a spurious positive correlation that will result in the an upwardly biased coefficient of the immigration-native ratio. Our theoretical model takes some account of these channels and delivers an equation in which wages are related to the lagged immigrant-native ratio. But even the lagged immigrant ratio may not be clearly exogenous. Shocks that hit a region and occupation are likely to be correlated over time. This leads to serially correlated errors in the presence of which the lagged immigrant-native ratio will be correlated with the error term. In that case the coefficient on the lagged immigrant-native ratio reported under OLS may continue to be biased upwards.

To deal with the endogeniety issue we follow a similar approach to Card (2001) and Cortes (2008). This approach involves creating an instrument for the immigrant-native ratio by predicting the flow of immigration to different regions and occupations based on the historic settlement decisions of immigrants from different countries. ${ }^{12}$ This counterfactual path for immigration is based on the assumption that new immigrants that arrive in Britain tend to settle in regions where previous cohorts of immigrants - from the same country of origin as them - had decided to settle. So for example, a new Bangladeshi immigrant will tend to settle in a region where previous cohorts of Bangladeshi immigrants had decided to settle. This approach hopes to create a counterfactual path of immigration, across regions and occupations, which are exogenous to current labour demand conditions. In this paper, the start of our sample period, 1992, was used as the base year from which to capture the historic settlement pattern by considering the regional settlement choices of immigrants from 26 countries or country groups. (Appendix 1 provides more details).

A simple regression of the actual immigrant native ratio on the constructed counterfactual was strongly significant. ${ }^{13}$ The results of instrumenting the immigrant native ratio by using historic enclaves to predict the flow of subsequent immigrant settlement are shown in columns 4-6 of Table 2. The results reported are of a similar magnitude to the OLS results.

We found that the result of our regression did vary with the specification of the equation, the time period of estimation, and the methodology of estimation. For this reason we think it is best to consider a range of different specifications. Table 2 provides this range. Weighting occupation cells by the employment level of that occupation region cell (columns 2 and 5), helps us to down-weight smaller cells with large sampling errors; and doing this increases the coefficient a little above our basic result reported in column 1. We also allow errors within region-occupation cell to be correlated over time, and report standard errors that are heteroskadasticity robust and clustered by region-occupation in column 3 and 6 . This naturally pushes up the standard errors, and in some cases is enough to make the coefficient of interest turn insignificant. This is no surprise, as we are pushing the data quite hard, because we are estimating an 
equation with region, time and occupation dummies as well as region-by-time, occupation-by-time and region-by-occupation fixed effects - that is we are estimating 1175 fixed effects with 6875 observations - so a very large part of the panel variation is absorbed by the fixed effects. ${ }^{14}$ This means large standard errors of 0.04 are being used identify a coefficient that is estimated in the neighbourhood of -0.04 .

The main message to take away from Table 2 is that across a range of econometric specifications when the share of immigration rises, wages tend to fall. The magnitude of the impact, however, is small, with the coefficient taking on values between-0.02 and-0.08. This means that a 10 percentage point rise in immigration, which is the rise that Britain has seen over the past 25 years, is likely to reduce average wages by less than a percent. With average wages around $£ 14$ per hour this amounts to a reduction of less than 15 pence. We also note the positive impact of the unemployment rate, as expected from our theoretic model.

We also investigate whether there is any difference between the inflow of new immigrants (arrived in the last two years) and old immigrants (the remainder). We find that the impact of immigration on wages is driven by the stock of total immigrants, not by the inflow of new ones.

Turning to estimates of dynamic versions of our key equation, these are presented in Table 3. With 25 time periods, the standard bias on the lagged dependent variable coefficients when estimating fixed effects models is small, so we ignore this problem (see Nickell 1981). The overall picture from the dynamic specification is similar to that of the static specification. The impact of immigration on wages exhibits some persistence, but the long-run coefficient is similar to the static model. For example in column (2) where we include two lags of immigration, the long run coefficient is-0.025 (that is, $(-0.014) /(1-0.433))$, which is similar to the corresponding static coefficient in Table 2

Table 3 The Impact of Immigration on Wages, Dynamic Model (Eq. 7)

\begin{tabular}{|c|c|c|c|c|c|c|}
\hline \multicolumn{7}{|l|}{ Dependent Variable, $\operatorname{Ln} \mathrm{W}_{\text {irt }}$} \\
\hline & (1) & (2) & (3) & (4) & (5) & (6) \\
\hline & \multicolumn{3}{|c|}{ Not weighted } & \multicolumn{3}{|l|}{ Weighted } \\
\hline \multirow[t]{2}{*}{$\operatorname{Ln~W~}_{\text {irt-1 }}$} & & $0.433^{* * *}$ & $0.427^{* * *}$ & & $0.519^{* * *}$ & $0.510^{* * *}$ \\
\hline & & {$[0.012]$} & {$[0.013]$} & & {$[0.012]$} & {$[0.012]$} \\
\hline \multirow[t]{2}{*}{$(\text { Immigrant/native ratio) })_{\text {irt-1 }}$} & $-0.023^{* * *}$ & $-0.014^{* *}$ & -0.010 & $-0.034^{* * *}$ & $-0.010 * * *$ & -0.003 \\
\hline & {$[0.008]$} & {$[0.007]$} & {$[0.009]$} & {$[0.007]$} & {$[0.006]$} & {$[0.009]$} \\
\hline \multirow[t]{2}{*}{$(\text { Immigrant/native ratio) })_{\text {irt-2 }}$} & & & -0.005 & & & $-0.015^{* *}$ \\
\hline & & & {$[0.010]$} & & & {$[0.009]$} \\
\hline \multirow[t]{2}{*}{ Unemployment rate ${ }_{\text {irt-1 }}$} & $0.067^{*}$ & 0.013 & 0.001 & 0.048 & 0.048 & 0.035 \\
\hline & {$[0.036]$} & {$[0.032]$} & {$[0.033]$} & {$[0.032]$} & {$[0.032]$} & {$[0.034]$} \\
\hline \multirow[t]{2}{*}{ Unemployment rate ${ }_{\text {irt-2 }}$} & & & 0.039 & & & 0.047 \\
\hline & & & {$[0.033]$} & & & {$[0.034]$} \\
\hline Sample Size & 6,468 & 6,449 & 6,133 & 6,468 & 6,449 & 6,133 \\
\hline Adjusted $R^{2}$ & 0.993 & 0.995 & 0.995 & 0.996 & 0.997 & 0.997 \\
\hline \multicolumn{7}{|c|}{$\begin{array}{l}\text { Notes: } \\
\text { a Notes d and e from Table } 2 \text {. } \\
\text { b Equations in column (1), (2) ad (3) are estimated using OLS. Columns (4), (5) and (6) are also estimated using OLS and } \\
\text { by weighting each cell by employment. } \\
\text { c With } 25 \text { time periods, the standard bias on the lagged dependent variable coefficients when estimating fixed effects } \\
\text { models is small, so we ignore this problem (see Nickell, 1981). } \\
\text { Sources: LFS and ASHE/NES. }\end{array}$} \\
\hline
\end{tabular}


$(-0.023)$. We experiment with adding further lags of the exogenous variables, but we do not find these to be significant. They may be in other specifications.

How should one interpret these findings? Our theoretical model outlined above suggests certain conditions that must hold in order for the impact of the immigrant-native ratio on wages to be negative. These include: (i) that firms believe (rightly or wrongly) that immigrants are less productive than natives and (ii) that immigrants have lower reservation wages than natives or that occupation/region labour supply is likely to be enhanced by the presence of existing immigrants. Our findings cannot tell us anything about any of the above conditions in isolation, rather they suggest that either both conditions are true or that only one is true but its impact is large enough to dominate.

What should monetary policymakers make of these findings? The UK Monetary Policy Committee (MPC) cares about migration because changes in the level of immigration can alter the level of wages consistent with the inflation target. ${ }^{15}$ While immigration clearly increases the supply of labour, immigrants are consumers too and so the demand for goods and labour rise too (see King (2007); Barwell (2007)). Here we have found immigration to have a small, significant, negative impact on UK average wages. This suggests that the supply effects have dominated the demand effects over our sample period - 1992-2016.

\subsection{Occupational-level specification}

So while immigration appears to have had a negative impact on occupational pay, the overall average effect is relatively small. It is natural to ask whether we can find bigger effects in particular occupations. To do this, we divide the 25 2-digit occupations into four groups: managers and professionals, skilled production workers, semi/unskilled production workers, and semi/unskilled services workers. ${ }^{16}$

There is no particular reason to expect the parameters in the theoretical model to be the same across occupations. Rather, one might expect there to be heterogeneity across occupations. This heterogeneity probably reflects a variety of factors. It may be the case that immigrants may be perceived as being more productive than natives in some occupations but not in others. It may be that different occupations have been hit by different shocks or that different occupations have been hit by the same shocks but to differing degrees. For example, it may be the case that immigrants entering skilled jobs have done so primarily as a result of a positive demand shock. Faced with shortages of these skilled workers, firms may need to be more active in recruitment and offer competitive wages to attract foreign workers. At the other end of the spectrum, it may also be the case that immigrants entering semi/unskilled service jobs have done so primarily as a result of supply shocks (such as the 2004 EU Accession). In this case, their reservation wages may be lower than those of natives, reflecting the lower wage rates they might earn in their home countries. These examples highlight how potential differences in immigrant and firm behaviour across occupations can show up as differences in the impact of immigration on wages across occupations.

Estimates across these four broad occupation groups are reported in Table $4 .{ }^{17}$ For each occupation, the static equation results are reported in the first row and the dynamic equation results in the second row. Panel A reports the results under OLS, and Panel B under 
Table 4 Impact of Immigration on Wages: by Occupation Groups

\begin{tabular}{|c|c|c|c|c|c|c|}
\hline & Ln (wages) $)_{\text {irt-1 }}$ & & $\begin{array}{l}\text { Immigrant/ } \\
\text { native } \\
\text { ratio)irt-1 }\end{array}$ & $\begin{array}{l}\text { Robust Standard } \\
\text { Errors }\end{array}$ & $\begin{array}{l}\text { Sample } \\
\text { Size }\end{array}$ & $\begin{array}{l}\text { Adjusted } \\
\text { R-squared }\end{array}$ \\
\hline \multicolumn{7}{|c|}{ Panel A: OLS estimation (Weighted) } \\
\hline \multirow[t]{2}{*}{ Managers \& Professionals } & & & -0.239 & {$[0.157]$} & 2809 & 0.806 \\
\hline & $0.943^{* * *}$ & {$[0.015]$} & $-0.054^{* * *}$ & {$[0.019]$} & 2796 & 0.981 \\
\hline \multirow[t]{2}{*}{ Skilled Production } & & & $-0.130^{* * *}$ & {$[0.046]$} & 1022 & 0.872 \\
\hline & $0.946^{* * *}$ & {$[0.017]$} & $-0.015^{* * *}$ & {$[0.004]$} & 1016 & 0.985 \\
\hline \multirow[t]{2}{*}{ Semi/unskilled production } & & & 0.002 & {$[0.034]$} & 792 & 0.929 \\
\hline & $0.934^{* * *}$ & {$[0.012]$} & -0.005 & {$[0.004]$} & 792 & 0.991 \\
\hline \multirow[t]{2}{*}{ Semi/unskilled services } & & & $-0.152^{* * *}$ & {$[0.028]$} & 1318 & 0.949 \\
\hline & $0.850^{* * *}$ & {$[0.027]$} & $-0.024^{* * *}$ & {$[0.006]$} & 1318 & 0.985 \\
\hline \multicolumn{7}{|c|}{ Panel B: IV estimation (Weighted) } \\
\hline \multirow[t]{2}{*}{ Managers \& Professionals } & & & $-0.394^{* *}$ & {$[0.167]$} & 2807 & 0.804 \\
\hline & $0.918^{* * *}$ & {$[0.017]$} & $-0.056^{* *}$ & {$[0.017]$} & 2794 & 0.975 \\
\hline \multirow[t]{2}{*}{ Skilled Production } & & & $-0.132^{* * *}$ & {$[0.037]$} & 1011 & 0.872 \\
\hline & $0.946^{* * *}$ & {$[0.015]$} & $-0.016^{* * *}$ & {$[0.005]$} & 1005 & 0.985 \\
\hline \multirow[t]{2}{*}{ Semi/unskilled production } & & & 0.048 & {$[0.040]$} & 792 & 0.921 \\
\hline & $0.934^{* * *}$ & {$[0.012]$} & 0.001 & {$[0.009]$} & 792 & 0.991 \\
\hline \multirow[t]{2}{*}{ Semi/unskilled services } & & & $-0.259^{* * *}$ & {$[0.085]$} & 1317 & 0.931 \\
\hline & $0.844^{* * *}$ & {$[0.026]$} & $-0.034^{* * *}$ & {$[0.011]$} & 1317 & 0.985 \\
\hline
\end{tabular}

Notes:

a All specifications use clustered robust standard errors, and all equation are weighted using the levels of employment by each occupation and region cell

${ }^{b}$ Each equation also includes lagged unemployment, age controls, skill controls, year dummies, and region dummies

${ }^{b}$ Notes (d)- (e), Table 2; Note (c), Table 3.

Sources: LFS and ASHE/NES

IV estimation. All equations are weighted by employment of each occupation-region cell, and all equations are estimated using clustered robust standard errors. The OLS and IV findings are broadly similar, so we focus on our preferred IV method of estimation.

Not surprisingly, the results show that there are clear differences, in the impact of immigration on wages, across occupations. The static results suggest that the statistically significant negative effects of immigration on wages are concentrated among skilled production workers, and semi/unskilled service workers. In the latter cases, the coefficients indicates that a 10 percentage point rise in the proportion of immigrants working in semi/unskilled services - that is, in care homes, bars, shops, restaurants, cleaning, for example - leads to a 2.6 percent reduction in pay.

What should we make of this finding? Our earlier investigation into the facts about immigration unveiled that low-skill occupations, such as semi-unskilled services, had witnessed the largest increases in immigration in recent years. If immigrants in these occupations earn less than natives, the 2.6 percent negative impact of immigration on wages reported above could simply reflect compositional changes within the occupation, towards a higher share of (lower paid) immigrants. The compositional effect will be determined by the wage differential between immigrants and natives within occupations. ${ }^{18}$ A simple hourly wage equation suggests that, in semi/unskilled services, immigrants earn 7.0 percent less than natives (Table 5). ${ }^{19}$ In other words a $10 \%$ rise in immigration alone, would lead to a 0.7 percent fall in wages - that is the size of the 
Table 5 Wage equations: all occupations and by occupational groups

\begin{tabular}{|c|c|c|c|c|}
\hline \multicolumn{5}{|c|}{ Dependent variable, In(hourly wage $_{k t}$ ) } \\
\hline & $\begin{array}{l}\text { Immigrant/ } \\
\text { native ratio) }\end{array}$ & $\begin{array}{l}\text { Robust Standard } \\
\text { Errors }\end{array}$ & Sample Size & $\begin{array}{l}\text { Adjusted } \\
\text { R-squared }\end{array}$ \\
\hline All occupations & $-0.077^{* * *}$ & {$[0.002]$} & 792,333 & 0.484 \\
\hline Managers \& Professionals & $-0.061^{* * *}$ & {$[0.003]$} & 341,148 & 0.215 \\
\hline Skilled Production & $-0.180^{* * *}$ & {$[0.006]$} & 62,045 & 0.223 \\
\hline Semi/unskilled production & $-0.143^{* * *}$ & {$[0.004]$} & 76,646 & 0.167 \\
\hline Semi/unskilled services & $-0.070^{* * *}$ & {$[0.003]$} & 205,587 & 0.189 \\
\hline
\end{tabular}

Notes:

${ }^{a}$ All equations are estimated using ordinary lease squares.

b Each equation also contains age, age squared, skill controls (share of native population with degree, with completed school, still in education), region dummies, year dummies and 2-digit occupation dummies.

${ }^{c} \mathrm{t}=$ time (14 years, 2001-20164), the $\mathrm{k}$ subscript captures the fact that this is a micro regression of the wages of individuals on their personal characteristics.

Source: LFS.

compositional effect. It is striking that the compositional effect is small when compared to the large impact of 2.6 percent reported above. From this we conclude that the impact of immigration on wages in semi/unskilled services is much larger than can be accounted for by purely compositional effects, suggesting that the vast majority of this effect refers to the impact on native workers.

The same cannot be said for skilled production workers. Here a $10 \%$ rise in immigration lowers wages by $1.32 \%$, but the compositional effect is in the same ball park, around $1.43 \%$. So for skilled production workers the impact of immigration on wages can largely be accounted for the compositional effect.

\subsection{EU vs non-EU}

Given the recent rise in immigration from the EU, and particularly from the new EU countries, and the ongoing debate about the UK's membership in the EU it is natural to ask if the impact of immigration on wages is different for EU and non-EU immigrants. In other words, does the impact on wages depend on where the immigrant comes from?

There are many different econometric specifications that would allow us to test for such a differential effect. Our preferred specification is to build this aspect in to our existing model/ equation, which considers the impact of the immigrant-native ratio on wages. To this equation, we add in an additional term that reflects the composition of EU and non-EU immigration. If that term is found to be statistically significant, then it would mean that, for a given number of immigrants, a larger share of EU immigrants has an additional impact on wages.

We find that the ratio of EU to non-EU immigrants has a very small impact on wages, and it is statistically significant in some specifications but not others (Table 6). From column 1 in Table 6 we conclude that a 10 percentage point rise in immigration, but holding constant the EU/non-EU immigrant ratio, would lower overall wages by $0.21 \%$. And if a 10 percentage point rise in immigration was accompanied by a $10 \%$ rise in EU immigration, overall wages would also likely fall by $0.21 \%$. There is no difference between these two numbers. This leads us to conclude that for a given immigrant native ratio, a greater (or lower) share of immigrants from the EU does not alter the overall impact of immigration on wages. And even if one were to consider the results of the IV estimation, the fact that the ratio of EU to non-EU immigrants is insignificant throughout suggests that the 
Table 6 EU vs Non-EU (all skills levels)

\begin{tabular}{|c|c|c|c|c|c|c|}
\hline \multicolumn{7}{|c|}{ Dependent Variable, Ln W $_{\text {irt-1 }}$} \\
\hline & (1) & (2) & (3) & (4) & (5) & (6) \\
\hline & $\begin{array}{l}\text { Not } \\
\text { weighted }\end{array}$ & Weighted & $\begin{array}{l}\text { Weighted, robust } \\
\text { S.E.S }\end{array}$ & $\begin{array}{l}\text { Not } \\
\text { weighted }\end{array}$ & Weighted & $\begin{array}{l}\text { Weighted, robust } \\
\text { S.E.S }\end{array}$ \\
\hline & OLS & & & IV & & \\
\hline \multirow{2}{*}{$\begin{array}{l}\text { (Immigrant/native } \\
\text { ratio) })_{\text {irt-1 }}\end{array}$} & $-0.021^{* * *}$ & $-0.034^{* * *}$ & -0.034 & -0.035 & $-0.089^{* * *}$ & -0.089 \\
\hline & $(0.008)$ & $(0.007)$ & $(0.041)$ & $(0.016)$ & $(0.012)$ & $(0.089)$ \\
\hline \multirow{2}{*}{$\begin{array}{l}\text { (EU/non-EU } \\
\text { immigrant } \\
\text { ratio) irt-1 }\end{array}$} & 0.000 & $0.001^{* *}$ & $0.001^{* *}$ & 0.003 & -0.010 & -0.01 \\
\hline & $(0.000)$ & $(0.001)$ & $(0.001)$ & $(0.023)$ & $(0.014)$ & $(0.015)$ \\
\hline \multirow{2}{*}{$\begin{array}{l}\text { Unemployment rate } \\
\text { irt-1 }\end{array}$} & $0.075^{* *}$ & $0.092^{*}$ & $0.092^{*}$ & 0.071 & 0.032 & 0.032 \\
\hline & $(0.036)$ & $(0.038)$ & $(0.050)$ & $(0.101)$ & $(0.045)$ & $(0.089)$ \\
\hline Sample Size & 6,418 & 6,418 & 6,418 & 6,418 & 6,418 & 6,418 \\
\hline Adjusted $R^{2}$ & 0.993 & 0.996 & 0.996 & 0.993 & 0.996 & 0.996 \\
\hline
\end{tabular}

Notes:

a Notes $\mathrm{d}$ and e from Table 2.

Sources: LFS and ASHE/NES

impact of immigration on wages is driven mainly by the overall stock of immigration, with its composition - EU vs non-EU - having a second order impact. Importantly this finding is dependent on the sample period that we estimate over.

We have explored different specifications of estimating whether there is any differential impact between EU and non-EU immigrants. For example we considered a specification where the EU immigrant native ratio enters the regression alongside the non-EU immigrant native ratio. This specification also led us to the same findings: that the coefficients on the EU and non-EU immigrant native ratios were no different to each other, implying there is no differential impact between EU and non-EU immigrants on wages. That said the results of such a specification were noisy, and in our view harder to interpret. We attributed this noise in part due to the fact that the values of the EU immigrant native ratio were small and volatile across regions and occupation in at the start of our sample, and in part to the fact that both the EU and non-EU immigrant ratio had a common denominator (the number of natives) which we believe may give rise to multicollinearity and bias our parameter estimates.

Does this result - that there is no different between EU and non-EU migrants on wages - also hold within different occupations? Broadly yes. Table 7 shows that in the static model (first row of each occupation) there is absolutely no difference between EU and non-EU immigration on wages for all occupations. In the dynamic model there is some variability, with the EU composition being important for skilled production and semi/unskilled services. But the coefficients are tiny. To take an example, if the immigrant share in semi/unskilled services were to rise by 10 percentage points, with a corresponding $10 \%$ rise in the share of EU immigrants, the downward impact on wages would be $1.92 \%$ as opposed to $1.88 \%$ if there were no change in the EU share. This is a relatively small difference. Of course if the wave of EU migrants were to continue to rise, this differential could become large enough to be important, but for now we do not consider it to be material.

\section{Conclusions}

This paper asks whether immigration has any impact on average wages, and answers that question by extending the previous analysis of migration to incorporate the 
Table 7 EU vs. Non-EU by skill

\begin{tabular}{|c|c|c|c|c|c|c|c|c|}
\hline \multicolumn{9}{|c|}{ Dependent Variable, $\mathrm{Ln}_{\mathrm{W}} \mathrm{Wit}-1$} \\
\hline \multicolumn{9}{|c|}{ IV estimation (Weighted) } \\
\hline & In wirt-1 & $\begin{array}{l}\text { Robust and } \\
\text { clustered } \\
\text { S.E.S }\end{array}$ & $\begin{array}{l}\text { Immigrant/ } \\
\text { native ratio }\end{array}$ & $\begin{array}{l}\text { Robust and } \\
\text { clustered } \\
\text { S.E.s }\end{array}$ & $\begin{array}{l}\text { EU/non-EU } \\
\text { immigrant } \\
\text { ratio }\end{array}$ & $\begin{array}{l}\text { Robust and } \\
\text { clustered } \\
\text { S.E.S }\end{array}$ & $\begin{array}{l}\text { Sample } \\
\text { size }\end{array}$ & $\bar{R}^{2}$ \\
\hline \multirow[t]{2}{*}{$\begin{array}{l}\text { Managers \& } \\
\text { Professionals }\end{array}$} & & & -0.372 & $(0.186)$ & -0.019 & $(0.074)$ & 2563 & 0.80 \\
\hline & $-0.936^{* * *}$ & $(0.016)$ & $-0.097^{* *}$ & $(0.025)$ & 0.008 & $(0.007)$ & 2552 & 0.98 \\
\hline \multirow[t]{2}{*}{ Skilled Production } & & & $-0.172^{* * *}$ & $(0.049)$ & 0.001 & $(0.003)$ & 911 & 0.87 \\
\hline & $-0.945^{* * *}$ & $(0.017)$ & $-0.020^{* * *}$ & $(0.006)$ & 0.001 & $(0.002)$ & 905 & 0.98 \\
\hline \multirow[t]{2}{*}{$\begin{array}{l}\text { Semi/unskilled } \\
\text { production }\end{array}$} & & & -0.036 & $(0.063)$ & -0.108 & $(0.050)$ & 725 & 0.71 \\
\hline & $-0.936^{* * *}$ & $(0.012)$ & 0.007 & $(0.014)$ & $-0.009^{* *}$ & $(0.004)$ & 725 & 0.99 \\
\hline \multirow[t]{2}{*}{$\begin{array}{l}\text { Semi/unskilled } \\
\text { services }\end{array}$} & & & $-0.188^{* * *}$ & $(0.028)$ & 0.004 & $(0.003)$ & 1206 & 0.94 \\
\hline & $-0.838^{* * *}$ & $(0.028)$ & $-0.036^{* *}$ & $(0.016)$ & -0.003 & $(0.007)$ & 1206 & 0.98 \\
\hline \multicolumn{9}{|c|}{$\begin{array}{l}\text { Notes: } \\
\text { a All equation are estimate using clustered robust standard errors, and all equations are weighted using the level of } \\
\text { employment in each occupation and region cell } \\
\text { b All equations are estimated using IV regressions, and they are all weighted regressions that use the employment in } \\
\text { each region occupation cell as weights. } \\
\text { c Each equation also includes lagged unemployment, age controls, skill controls, year dummies, and region dummies } \\
\text { d Notes d and e, Table 2; Note (iii), Table } 3 \text {. } \\
\text { Sources: LFS and ASHE/NES }\end{array}$} \\
\hline
\end{tabular}

occupational dimension. Occupation turns out to be a relatively important dimension that needs to be taken account of in an empirical analysis of immigration. We find that the immigrant-native ratio has a significant small impact on the average occupational wage rates of that region. A 10 percentage point rise in immigration will tend to lower average wages by between $0.2-0.8$ per cent. But as noted earlier in the text, it is important to note that this equates to a very small impact on nominal pay. Closer examination reveals that the biggest effect of immigration has been on the wages of workers in the semi/unskilled services sector - here a 10 percentage point rise in the proportion of immigrants is associated with a 2.6 percent reduction in pay. These findings accord well with intuition and anecdotal evidence, but have not been recorded previously in the empirical literature.

This paper also considers whether there is any differential impact of EU vs non-EU immigrants on wages. The paper starts by arguing that there are good reasons to suspect there will be a differential impact on wages, because immigrants from the EU are different to non-EU immigrants. They tend to be on average more educated and have higher labour force participation rates than their non-EU counterparts. But our empirical results reveal that for now, where an immigrant comes from - be it the EU or non-EU - does not have any differential impact on wages. Both EU and non-EU immigrants have a small similarly sized negative impact on wages. These findings are likely to be a useful for future research.

\section{Endnotes}

${ }^{1}$ This paper is an update of a Bank of England working paper published in 2015 - see Nickell and Saleheen (2015). It is worth noting that this paper is also an update and extension of paper previously published in 2008 under the title "The impact of immigration on 
occupational wages: British Evidence' (See Nickell and Saleheen (2008). There are three main differences between this paper and the 2008 version of the paper. First the previous version of the paper did not consider how EU immigrants differ from non-EU immigrants. So this aspect is completely new to this paper. Second, the previous paper was based on the sample period 1992-2006, whereas this paper has been extended to cover 1992-2016. The extra 10 years of data, clearly mean some of the empirical estimates have changed, but the qualitative findings of the paper remain intact. Third, we believe that the empirical methodology - in particular the identification strategy - has been improved in this paper.

${ }^{2}$ This would appear to be at variance with standard economics based on supply and demand. The most convincing explanation is that there is a weaker adoption of advanced technology, which is complementary to skilled labour, in the presence of larger numbers of the unskilled. This would offset the wage effects of shifts in the proportion of unskilled workers. See Lewis $(2004,2005)$ and Beaudry et al. (2006), for evidence in favour of this explanation.

${ }^{3}$ We thank an anonymous referee for suggesting that we use this approach.

${ }^{4}$ See the reference to this U-shaped pattern in immigration in Saleheen and Shadforth (2006).

${ }^{5}$ Of course immigrants may typically work longer hours than natives, and our analysis of hourly wages does not incorporate those differences.

${ }^{6}$ Each dot in the chart represents the average wage for each occupation divided by the average wage for all occupations.

${ }^{7}$ Of course, in practice, we would have to split employees into age/education groups within occupations to make this assumption totally realistic. These factors are controlled for in the empirical analysis.

${ }^{8}$ The Annual Survey of Hours and Earnings was previously called the New Earnings Survey (NES).

${ }^{9}$ The 2016 data only goes up to Q3, as the Q\$ data is still unavailable.

${ }^{10}$ For more information on this measure of skill, and the problems it helps overcome, see Saleheen and Shadforth (2006) or Manacorda, Manning, and Wadsworth (2012).

${ }^{11}$ For a discussion of the accuracy of immigration data see the box on page 376-377 of Saleheen and Shadforth (2006).

${ }^{12}$ It is worth noting that the creation and use of this instrument is a new aspect to this paper. In previous versions of this paper, Nickell and Saleheen (2008) and Nickell and Saleheen (2015), the immigrant native ratio we instrumented with the lagged immigrant native ratio.

${ }^{13}$ The coefficient was 0.8 and the $\mathrm{t}$-statistic was nearly 70 in a simpler regression of the immigrant native ratio on the instrumented immigrant native ratio. The regression included industry, region and occupation dummies.

${ }^{14}$ This point is also made by Aydemir and Borjas (2011) and Ottaviano and Peri (2012).

${ }^{15}$ See MPC minutes in July 2015.

${ }^{16}$ Details of these classifications may be found in Appendix 1.

${ }^{17}$ Estimates based on each of the detailed 25 occupations can also be seen in Table A3 (for the static model) and Table A4 (for the dynamic model). Note that the average of the coefficients reported in Table A3 - that is the average across the 25 occupational equations - is -0.07 , within the range of results obtained from estimating the pooled model that is reported in Table 2. 
${ }^{18}$ The wage data that we have used thus far (from the NES) are not broken down into immigrant and native sub-groups. But the LFS survey that we have used for data on immigration does have individual information on wages and so can by split by natives and immigrants. The LFS wage data comes from a smaller sample and so is of a lower quality than NES wage data, nevertheless it is useful in indicating whether immigrants earn more or less than natives.

${ }^{19}$ Across all occupations immigrants earn 7 percent less than natives (Table 5).

${ }^{20}$ See for example Tijdens (2014).

\section{Appendix 1}

\subsection{Dataset Construction And Defiinition Of Variables}

\subsubsection{Occupations: a major change in their classification}

An important data problem encountered was that the standard classification of occupations, a key variable in our approach, changed in 2000/2001. This was reflected by a major change in the classification of occupations from Standard Occupation Classification (SOC) 1990 to SOC 2000 in 2001/2002.

There were two main reasons to reclassify occupations: the need to improve alignment with international standards and the need to bring the classification up to date to reflect changes to society. Changes such as the increased use of computing, the development of new occupations related to the environment, conservation and the emergence of remote servicing provisions (e.g. call centres).

This paper therefore devises a novel methodology to transform old occupational classification (SOC 1990) into the new classification (SOC 2000). Doing this allows us to create our data set on consistent definition of occupation over a long time period.

\subsubsection{Creating a consistent occupational classification: Transforming SOC 1990 to SOC 2000}

The Office of National Statistics (ONS) does not provide a match between SOC 1990 and SOC 2000. Indeed, they argue that there is no "formula" that will allow one simply to match the two classifications. In other words, if one were to classify 100 people into the SOC 1990 and SOC 2000 occupations, it is unlikely that all the people from a single category of SOC 1990 would end up in the same single category of SOC 2000. Instead, individuals from one category of SOC 1990 are likely to end up in multiple categories of SOC 2000.

To find a mapping from SOC 1990 to SOC 2000 we first calculate a matrix that allocates the same people to both sets of codes is derived. Such a dual coding of occupations for the same people is obtained from the panel component of neighbouring LFS surveys. The LFS 2000:Q4 survey coded occupations based on SOC 1990. And the LFS 2001:Q1 survey coded occupations based on SOC 2000. Taking the individuals who were surveyed in both quarters and who did not change jobs during that time, one is able to obtain 55,000 individuals with dual occupational codes. This provides us with a single point-in-time dual matching of occupational codes. This provides us with a matrix that links the two occupational codes - the rows are the old codes that map to the columns which are the new codes.

This matrix of dual occupation codes is the key building block that allows us to derive a mapping of individuals from SOC 1990 to SOC 2000. As the mapping is not one-to-one (the off diagonal cells are non-zero), a "proportional" mapping method is used. Proportional mapping is a method in which a given proportion of individuals in each old occupational category (SOC 1990) is assigned to one 
category in the new occupational classification (SOC 2000), with another proportion being assigned to another category in SOC 2000, and so on. The proportions that need to be assigned to each category are determined by the elements of the matrix. For example, assume that there are only two categories of SOC 1990 and SOC 2000. And assume that 70 percent of individuals in category 1 of SOC 1990 fall into category 1 of SOC 2000, and 30 percent fall into category 2. Then, the proportions of SOC 1990 individuals going to categories 1 and 2 will be 0.7 and 0.3 , respectively. In the paper, 3-digit SOC 1990 (371 categories) is mapped into 2digit SOC 2000 (25 categories)

This matrix or mapping between the two occupations allows any variable that is defined on the SOC 1990 basis to be transformed into the SOC 2000 basis. Take the share of immigrants as an example. One can take the share of immigrants by old occupation and create the share of immigrants by new occupations, by multiplying by our matrix. Such a transformation has to be applied to all the variables that are used in our dataset.

For variables that are derived from the LFS, the occupational codes change in 2001, and for variables that are derived from ASHE/NES, the occupational codes change in 2002.

It is important to note that one drawback of our method is that the transformation matrix of occupations relates to a single point in time and as such this matrix is time invariant at the point at which the occupational classification changed in 2001. But we know from the Office of National Statistics that there is a continued effort to improve the measurement of statistics, particularly those reflecting modern society. And as such, one could imagine that, if the dual occupational coding of individuals (on the old and new classification) were to have continued over time, the elements of the transformation matrix may well have changed reflecting structural changs across occupations and/or improved methods of measurement. ${ }^{20}$ Unfortunately our study is unable to capture those changes.

\subsubsection{Definition of Variables}

The data used for our analysis come from the British Labour Force Survey (LFS) and the Annual Survey of Hours and Earnings (ASHE)/New Earnings Survey (NES). The LFS is a quarterly sample survey of households living at private addresses in Great Britain and is carried out by the Office of National Statistics. The LFS surveys about 100,000 individuals each quarter on a range of issues, including employment characteristics; information on earnings is only collected for $20 \%$ of the sample. The ASHE/NES is an annual employee survey that captures the level and distribution of earnings and hours worked by employees in Great Britain. It is based on a 1 percent sample of employees who are members of Pay-As-You-Earn (PAYE) income tax schemes. This survey covers the pay of around 180,000 individuals each year. It is considered the most comprehensive source of earnings information, as for earnings, its' sample is 9 times larger than the LFS; moreover it is based on hard payroll data rather than relying on individual memory of how much they were paid. The ASHE does not cover the earnings of the self-employed, or those who were not paid in the reference period.

We use data from these two sources to form a panel dataset that has three dimensions: time, region, and occupation. In other words, for each year of the 25 years (1992-2016) of data that we consider, there are observations for each of the 11 U.K. standard Government Office Regions, and within each region there is information on each of the 25 occupations defined at the 2-digit SOC 2000 classification. In total, in the absence of missing observations, the dataset will have a 
maximum of $6875(=25 \times 11 \times 25)$ observations. If there is no observation for a given cell, then that data point is missing. A typical static regression has 6400 observations.

\section{Region:}

Standard Government Office Regions (GORs).

\section{Occupation:}

In our panel dataset, occupations are classified according to SOC 2000 throughout. Table 8 set out some example occupations for each 2-digit occupation category. The 1 digit category can be derived by considering the first digit of each figure in the middle column. In Table 5, results are presented on various groups of occupations. The 2-digit occupations we use are set out in Table 8. The groups used in Table 5 are managers $(11,12)$, professionals $(21,22,23,24,31,32,35)$, skilled production workers $(51,52,53$, 54) semiskilled/unskilled production workers (81, 82, 91), and semiskilled/unskilled services workers $(61,62,71,72.92)$.

Table 8 - Occupations - what types of jobs do they include?

\begin{tabular}{|c|c|c|}
\hline Corporate managers & 11 & $\begin{array}{l}\text { Senior officials in national government, managers in } \\
\text { construction, marketing and sales. IT managers }\end{array}$ \\
\hline Managers and proprietors in agri and services & 12 & $\begin{array}{l}\text { Farming managers, hotel managers, hairdressing and } \\
\text { beauty salon managers }\end{array}$ \\
\hline Science and technology professionals & 21 & Physicists, civil engineers, chemists \\
\hline Health professionals & 22 & Doctors, dentists, vets \\
\hline Teaching and research professionals & 23 & Higher education teachers \\
\hline Business and public service professionals & 24 & Solicitors, lawyers, chartered accountants, librarians \\
\hline Science and technology associate professionals & 31 & Technicians in labs, IT, building and civil engineering \\
\hline $\begin{array}{l}\text { Health and social welfare associate } \\
\text { professionals }\end{array}$ & 32 & Nurses, pharmacists, physicians \\
\hline Protective services (associate professionals) & 33 & Police, prison and fire services \\
\hline Culture, media \&sports (associate professionals) & 34 & Artists, actors, sports players \\
\hline $\begin{array}{l}\text { Business and public service (associate } \\
\text { professionals) }\end{array}$ & 35 & Train drivers, estate agents, insurance underwriters \\
\hline Administrative occupations & 41 & Credit controllers, data assistants, clerks \\
\hline Secretarial and related (admin) & 42 & Medical, legal, company secretaries, \\
\hline Skilled trades (agricultural) & 51 & Farmers, gardeners \\
\hline Skilled trades (metal and electrical) & 52 & Electricians, telecoms engineers, computer maintenance \\
\hline Skilled trades (construction and building) & 53 & Plumbers, carpenters, bricklayers, roofers, plasterers \\
\hline Skilled trades (textiles and printing) & 54 & Tailors, upholsters \\
\hline Caring personal service occupations & 61 & Child-minders, nursery nurses, animal care assistants \\
\hline Leisure and other personal service (caring) & 62 & Housekeepers, travel agents/assistants, caretakers, \\
\hline Sales occupations & 71 & Sales assistants, check-out staff \\
\hline Customer service occupations (sales) & 72 & Call centre staff \\
\hline Process, plant \& machine operatives & 81 & $\begin{array}{l}\text { Clothing cutters, tyre fitters, coal mine operatives, plastic } \\
\text { process operatives }\end{array}$ \\
\hline Transport, mobile machine drivers \& operatives & 82 & Crane drivers, taxi drivers, air/rail transport operatives \\
\hline Elementary trades, plant and storage & 91 & Packers, labourers, goods storage \\
\hline Elementary admin and service occs & 92 & $\begin{array}{l}\text { Postmen, shelf fillers, car park attendants, cleaners road } \\
\text { sweepers, bar staff, porters, waiters }\end{array}$ \\
\hline
\end{tabular}




\section{Wages:}

Nominal hourly wage rates of all full-time workers by region and occupation. Based on adult rates for those whose pay was not affected by absence during the week in which the survey was carried out.

Source: ASHE 2002-2016 online published data files from Table 3.6a based on SOC 2000. Prior to 2002, these data are constructed from the NES (1992-2001) micro data files, where occupations are defined at the 3-digit SOC 1990 level.

\section{Employment:}

Individuals aged 16-65 who report being in employment by region and occupation.

\section{Unemployment:}

The unemployment rate is measured by taking the number of individuals aged 16-65 who are unemployed according to the LFS definition and dividing by the total number of individuals aged 16-65 who are either employed or unemployed. The unemployment rate is constructed for each occupation and region cell. To compute unemployment rates by occupation we need to use information on individuals' last job - that is the occupation that the individual was employed in prior to becoming unemployed.

\section{Immigrant-native ratio}

The number of foreign born individuals (or "immigrants") aged 16-65 divided by the number of individuals aged 16-65 who were born in the United Kingdom ("natives"). This ratio is constructed for each occupation and region cell.

\section{EU immigrant-native ratio}

EU migrants are defined as those individuals who report being born in an EU country, and the UK has allowed that country access to the UK labour market. The set of countries that form part of the EU will therefore vary over time. For example, Estonia, Latvia, Lithuania, Poland, Hungary Czech Republic, Slovakia and Slovenia all joined the EU migrant's category in 2004, whereas Bulgaria and Romania joined in in 2012.

\section{New immigrant-native ratio}

"New" immigrants are defined as those immigrants (foreign-born workers) who arrived in the United Kingdom in the year of the survey or the previous calendar year. The "new" immigration-native ratio takes the number of new immigrants aged 16-64 in each occupation and region and divides it by the number of natives aged 16-64 in that same occupation and region.

\section{Old immigrant-native ratio:}

"Old" immigrants are defined as those immigrants (foreign-born workers) who are not new immigrants. They are defined as the difference between the total number of immigrants and the number of new immigrants. The "old" immigration-native ratio takes the number of old immigrants aged 16-64 in each occupation and region and divides it by the number of natives aged 16-64 in that same occupation and region.

\section{Age:}

The average age of natives and immigrants aged 16-64 by region and occupation.

\section{Education:}

The skill level of each region and occupation cell is measured by the level of education held by the native inhabitants aged 16-64 in each region and occupation cell. Four levels of education are defined and used in this paper: those who have a degree; those who have completed school; those who have incomplete or no schooling; and those who are still in full-time education. These educational variables are defined according to the age at which 
the worker left full-time education. Completing education at the age of 21 is used to proxy completion of a degree. If education was completed before the age of 16, it is taken to proxy incomplete schooling; and if education was completed between the ages of 16 and less than 21, it is taken to imply that schooling has been completed (see Saleheen and Shadforth 2006 for details). The skill control variables take the form of the share of natives who hold a degree, have completed school, have incomplete schooling, or are still in fulltime education. As defined, the sum of these four skill shares will sum to 1.

\section{Country of Birth}

In order to create an instrument for migration we need to classify immigrants according to their country of birth and consider where immigrants had historically settled. We consider 25 counties and country groups of birth. We were constrained in having a final 26 countries/regions of birth for two reasons. First the LFS data must have allowed for that country of birth option to be selected in the first year of our sample, 1992. This was not the case for all countries, for example there was no separate coding for those from Lithuania in 1992. Although the LFS country of birth classification has expanded over time: from 144 countries/regions being documented in 1992 to 212 by 2016. Second there must be at least one person from that country of birth in our region occupation cell in the base year, 1992. This is important, because if not, then we are unable to say anything about the settlement pattern of migrants from the country beyond 1992. If no one exists from that country for a particular cell, then that country needs to be grouped with another similar country.

In the first instance we used information from the following countries/regions of birth : Australia, Bangladesh, Canada, China, Czech Republic (formerly Czechoslovakia), Cyprus, Egypt, France, Ghana, Germany, Greece, Hong Kong, India, Iran, Ireland, Italy, Jamaica, Kenya, Lithuania, Malawi, Malay, Malta, Mauritius, Netherlands, New Zealand, Nigeria, Pakistan, Philippines, Poland, Portugal, Romania, Russia, Singapore, Somalia, South Africa, Spain, Sweden, Sri Lanka, Tanzania, Turkey, Uganda, USA and Zimbabwe, Other Western Europe, Other Eastern Europe, Other Africa, Other Middle East, Other Asia, Other Central and South America, Other rest of the world. Later some of these countries were grouped due to missing cells.

\section{Acknowlegements}

The authors would like to thank Ambrogio Cesa-Bianchi, Federico Di Pace, Alan Manning, Katharine Neiss, Gianmarco Ottaviano, Simon Price, James Talbot, Srdan Tatomir, Bob Triest, Kenneth Turnbull, Yolanda Kodrzycki, and seminar participants at the Federal Reserve Bank of Boston, the Bank of England, the National Bank of Poland, and the Austrian Central Bank. Furthermore, the authors are thankful to the anonymous referee and the editor useful comments. Responsible editor: Denis Fougère

Competing interests

The IZA Journal of Development and Migration is committed to the IZA Guiding Principles of Research Integrity. The authors declare that they have observed these principles.

\section{Publisher's Note}

Springer Nature remains neutral with regard to jurisdictional claims in published maps and institutional affiliations.

Author details

${ }^{1}$ Honorary Fellow, Nuffield College Oxford, Oxford, UK. ${ }^{2}$ Bank of England, Threadneedle Street, EC2R 8AH London, UK.

Received: 21 May 2016 Accepted: 13 April 2017

Published online: 11 October 2017

References

Altonji, Joseph and Card, David (1991), "The Effects of Immigration on the Labor Market Outcomes of Less-skilled

Natives", in Immigration, Trade and Labor, edited by J.M. Abowd and R. B. Freeman, University of Chicago Press. 
Aydemir A, Borjas G. "Attenuation Bias in Measuring the Wage Impact of Immigration". Journal of Labour. 2011;29:69-113. Barwell, Richard (2007), "The macroeconomic impact of international migration", Bank of England Quarterly Bulletin, 2007Q1: 48-58.

Beaudry, Paul, Mark Doms, and Ethan Lewis (2006), "Endogenous skill bias in technology adoption: city level evidence from the IT revolution," Federal Reserve Bank of San Francisco Working Paper no. 06-24.

Borjas G. "The labour demand curve is downward sloping". Q J Econ. 2003;116(4):463-86.

Borjas, George (2005), Labour Economics, Third Edition, McGraw-Hill Irwin publishers.

Borjas, George (2017), "The Wage impact of the Marielitos: A reappriasal", forthcoming in Industrial and Labour Relations Review.

Borjas G, Katz L. The Evolution of the Mexican-Born Workforce in the United States. In: George B, editor. Mexican Immigration to the United States. Cambridge: National Bureau of Economic Research Conference Report; 2007.

Card D. "The impact of the Mariel Boatlift on the Miami labour market". Ind Labor Relat Rev. 1990;43(2):245-57.

Card D. Immigrant inflows, native outflows, and the local labor market impacts of higher immigration. Journal of Labor Economics. 2001;19(1):22-64.

Card D. "Is the new immigration really so bad?". Econ J. 2005;115(507):300-23.

Card D, DiNardo J. Do immigrant inflows lead to native outflows?. The American Economic Review, Vol. 90, No. 2, Papers and Proceedings of the One Hundred Twelfth Annual Meeting of the American Economic Association (May, 2000), pp. 360-367.

Carney, Mark (2015), "The European Union, monetary and financial stability, and the Bank of England", speech St Peter's College, Cairncross Lecture, Oxford, available from the Bank of England website.

Cortes P. "The Effects of Low-Skilled Immigration on US Prices: Evidence from CPI Data". J Polit Econ. 2008;114(3):381-442.

Dustmann C, Fabbri F, Preston I. The impact of immigration on the British Labour Market. Econ J. 2005;115(507):324-41.

Dustmann C, Fabbri F, Preston I. The Effect of Immigration along the Distribution of Wages. Rev Econ Stud. 2013;80(1):145-73.

King, Mervyn (2007), Speech to a CBI Dinner in Wales, available from the Bank of England website.

Layard R.G., Nickell S.J. and Jackman R. (1991), Unemployment: Macroeconomic Performance and the Labour Market, First Edition, Oxford University Press.

Lewis, Ethan (2004), "Local open economies within the U.S.: how do industries respond to immigration?" Federal Reserve Bank of Philadelphia Working Paper no. 04-1.

Lewis, Ethan (2005), "Immigration, skill mix and the choice of technique," Federal Reserve Bank of Philadelphia Working Paper no. 05-8.

Lucas R. On the Mechanics of Economic Development. J Monet Econ. 1988;22:3-42.

Machin, Stephen (2003), "Wage inequality since 1975," in R. Dickens, P. Gregg, and I Wadsworth (eds.), The Labour Market Under New Labour, Palgrave Macmillan.

Manacorda M, Manning A, Wadsworth J. The impact of immigration on the structure of wages: theory and evidence from Britain. Eur Econ Assoc. 2012;10(1):120-51.

Nickell S. Biases in dynamic models with fixed effects. Econometrica. 1981:49(6):1417-26.

Nickell, Stephen and Saleheen, Jumana (2008), "The impact of immigration on occupational wages: British evidence", Federal Reserve Bank Boston Working Paper 6 (2008).

Nickell, Stephen and Saleheen, Jumana (2015), "The impact of immigration on occupational wages: evidence from Britain", Bank of England Working Paper no. 574.

Ottaviano G, Peri G. Rethinking the gains from immigration: theory and evidence from the U.S. J Eur Econ Assoc. 2012; 10(1):152-97.

Pesaran H, Smith R. Estimating long-run relationships from dynamic heterogeneous panels. J Econ. 1995;68:79-113.

Saleheen J, Shadforth C. The economic characteristics of immigrants and their impact on supply. Bank of England Quarterly Bulletin. 2006;Q4:374-85.

Tijdens, Kea (2014), "Reviewing the measurement and comparison of occupations across Europe", Amsterdam Institute for Advanced Labour Studies Working Paper 149.

Wooldridge, Jeffrey (2002), Econometric analysis of cross section and panel data, MIT Press.

\section{Submit your manuscript to a SpringerOpen ${ }^{\circ}$} journal and benefit from:

- Convenient online submission

- Rigorous peer review

- Immediate publication on acceptance

- Open access: articles freely available online

- High visibility within the field

- Retaining the copyright to your article 